\title{
An Introduction to Music Revival as Concept, Cultural Process, and Medium of Change
}

DOI:

10.1093/oxfordhb/9780199765034.013.019

\section{Document Version}

Accepted author manuscript

Link to publication record in Manchester Research Explorer

\section{Citation for published version (APA):}

Hill, J., \& Bithell, C. (2014). An Introduction to Music Revival as Concept, Cultural Process, and Medium of Change. In The Oxford Handbook of Music Revival (pp. 3-42). (Oxford Handbooks). Oxford University Press. https://doi.org/10.1093/oxfordhb/9780199765034.013.019

\section{Published in:}

The Oxford Handbook of Music Revival

\section{Citing this paper}

Please note that where the full-text provided on Manchester Research Explorer is the Author Accepted Manuscript or Proof version this may differ from the final Published version. If citing, it is advised that you check and use the publisher's definitive version.

\section{General rights}

Copyright and moral rights for the publications made accessible in the Research Explorer are retained by the authors and/or other copyright owners and it is a condition of accessing publications that users recognise and abide by the legal requirements associated with these rights.

\section{Takedown policy}

If you believe that this document breaches copyright please refer to the University of Manchester's Takedown Procedures [http://man.ac.uk/04Y6Bo] or contact uml.scholarlycommunications@manchester.ac.uk providing relevant details, so we can investigate your claim.

\section{OPEN ACCESS}




\section{Chapter 1}

\section{An Introduction to Music Revival as Concept, Cultural Process, and Medium of Change}

\section{Juniper Hill and Caroline Bithell}

NOTE: This is a post-print (Author's Accepted Manuscript) for:

'An Introduction to Music Revival as Concept, Cultural Process, and Medium of Change'.

In The Oxford Handbook of Music Revival ed. Caroline Bithell and Juniper Hill, pp. 3-42. New York: Oxford University Press, 2014.

Acts of revival, restoration, and renewal have been influential forces shaping and transforming musical landscapes and experiences across diverse times and places. In this volume we set out to examine the many faces and impacts of musical revival from a contemporary and global perspective. We offer a combination of theoretical essays and ethnographic case studies, many of which present new research on folk, traditional, indigenous, roots, world, and early music scenes in a variety of post-industrial, post-colonial, and post-war contexts. Supported by the insights and perspectives offered by a cohort of thirty contributors, we aim to (a) review and expand existing revival theories, and explore new avenues for understanding revival processes; (b) examine music revival as a crucial cultural process for constructing meaning and effecting socio-cultural change; (c) consider the potential of post-revival as a theoretical concept, and propose new paradigms for analyzing the transformative dimensions and contemporary ramifications of 
revival movements; and (d) reveal the extent to which the legacy of revivalist visions continues to shape our musical and social worlds.

$<1>$ The Significances of Revival

A music revival comprises an effort to perform and promote music that is valued as old or historical and is usually perceived to be threatened or moribund. Generally speaking, revival efforts engage a number of intertwined processes and issues. First, revivals are almost always motivated by dissatisfaction with some aspect of the present and a desire to effect some sort of cultural change. Revival agents usually have agendas specific to their socio-cultural or political contexts, and in this sense may also be regarded as activists. Second, identifying musical elements and practices as old, historical, or traditional, and determining their value, often involves selecting from or reinterpreting history and establishing new or revised historical narratives (a process implicating scholars as well as performers and promoters). Third, transferring musical elements from the past to the present (or from one cultural group perceived as preserving lifeways that are in direct continuity with the past to a cultural group that perceives itself as being more modern) entails a decontextualization and a recontextualization—or what Owe Ronström (1996 and this volume) refers to as shifts. Such recontextualization may be temporal, geographical, and/or social; the social shifts discussed in this volume include appropriations across class, gender, age, religion, ethnicity, nationality, and political persuasion. In the process of recontextualization, various transformations may take place. Fourth, the elements of activism and recontextualization inherent in revivals necessitate the establishing of legitimacy, in order to persuade others to accept the musical and cultural changes being 
promoted and to allow the appropriating group to be perceived as legitimate culture-bearers. The act of legitimization frequently relies upon invocations of authenticity. Fifth, revivals often spur the development of new methods and infrastructures for transmitting, promoting, and disseminating the revived music, which may involve festivals, competitions, educational institutions, organizations, government policies, recording and distribution companies, and so on. Finally, if successful, revival efforts may result in the establishment of new subcultures and affinity groups, or may become part of mainstream culture; we designate this phase as "postrevival" in order to highlight the profound and long-term impacts that revivals may have on music, society, and culture. These six themes - activism and the desire for change, the valuation and reinterpretation of history, recontextualization and transformation, legitimacy and authenticity, transmission and dissemination, and post-revival outgrowths and ramifications are the core themes running throughout the chapters in this collection. Each is discussed in more detail in later sections of this introductory chapter.

The intentional act of reviving, restoring, and reimagining the past for purposes of the present has been a recurring and important cultural phenomenon across cultures and eras. Revival as a label, however, is contentious, and several of the contributing authors to this volume challenge its appropriateness or modify the more normative assumptions on which it rests. Mark Slobin's earlier observations still capture some of the prevailing criticisms:

To revive means to bring back to life, and clearly this is not what we're talking about. In the first place, I don't think expressive culture really dies; you'd have to think of culture as a straight-line evolution to believe that, and I don't. I think of it more as a spiral, changing, but dipping back along the way. (1983: 37) 
While in many cases "revival" may be an inappropriate descriptor in its literal sense of resuscitation or resurrection, the concept nonetheless places an important emphasis on revivalists' perceptions and their desire to engage with the past. In this volume, then, we employ the term as a type of shorthand to encompass a range of more nuanced processes, some of which were suggested by Slobin (1983), namely regeneration, renaissance, revitalization, re-discovery, reshaping, re-interpretation, re-focusing, re-assessment, re-articulation. To these we might add reclamation, recovery, rescue, recuperation, restitution, restoration, renovation, reinvention, reimplimentation, reactivation, re-traditionalization, re-indigenization, re-appropriation, resumption, resurgence, recycling, reproduction, revision, and re-creation. As the ubiquitous "re" prefix suggests, what these processes share is a fundamental motivation to draw upon the past, and/or to intensify some aspect of the present. Ralph Linton's earlier definition of a nativistic movement as "any conscious, organized attempt on the part of a society's members to revive or perpetuate selected aspects of its culture" (1943: 230, emphasis added) offers another way of sidestepping an overly literal focus on revival. In its extended sense, revival may also be seen as continuity — a deliberate effort to retain or keep alive as opposed to literally bringing back from the dead - or as the act of making visible that which has been hidden.

Slobin continues his reservations about "revival":

Second, it's clear to many trained observers that even when people seem to be reviving things, that is, exhuming them and breathing life into them, what they get is something new. (1983: 37) 
The many case studies in this volume confirm that each instance of supposed revival results in some sort of transformation or innovation, whether it be a new musical style, new methods of transmission and performance, new functions and meanings, or even a new music (sub)culture. In paying attention to these transformations, we shift the emphasis from the past to the present and future and, in the process, further refine our understanding of revival and its ramifications. It is in this spirit that Ronström (this volume) emphasizes revival as a form of cultural production. Milstein, meanwhile, proposes that viewing revival as a "current" allows us to extend our enquiries to "musical movements that engage in revivalist activities without producing formal revivals" (this volume).

$<2>$ Revival Scholarship and Scholar-Revivalists

The history of the contentious concept of revival is closely connected to the (often underplayed) history of the involvement of scholars in revival processes and the changing intellectual trends that influenced them. The Oxford English Dictionary (third edition) indicates that the metaphorical application of revival to artistic and cultural practices (dating from 1587) predates both the use of the term in its literal sense of "restoration or return to life" (1608) and its use in association with religious activities (1702). According to John Haines (this volume), we owe this earlier metaphorical usage to the activities of fifteenth and sixteenth-century antiquarians - the earliest revivalists to debut in this volume-who attempted to resurrect and restore ancient music from antiquity (sometimes attempting to demonstrate - if not invent-connections between their local histories and what they perceived as the great ancient civilizations of Greece and Rome). After antiquarianism, the scholarly disciplines most engaged in music revival work were 
folklore, followed by ethnomusicology and musicology, with some important input from anthropology and history.

Two major intellectual trends of the nineteenth century would spur on scholars-cumrevivalists for generations. The first was the theory (or myth) of cultural evolution, with its emphasis on folklore as survivals of ancient practices among the peasants. The second was romantic nationalism — promulgated by the German philosopher Johann Gottfried von Herder (1744-1803) — with its belief that folk poetry and customs reflected the soul of the nation. Together, these led to the collection of folk music and other cultural artefacts and practices across many cultures, and to their promotion as the pure/authentic/historical/traditional/ancient cultural expressions of a nation, region, or ethnic group. Nationalistic agendas, concepts of cultural evolution, and fears that modernization would lead to a cultural grey-out—prevailing intellectual trends for much of the nineteenth century and in some cases into the mid twentieth century—led many folklorists, ethnomusicologists, and collectors to seek out and prioritize musical items that they viewed as culturally "pure" and old, avoiding those "contaminated" by the influence of foreign, urban, or modern culture (see, for example, Child 1861, Sharp 1907 and 1917, and Lomax 1968). These collectors and scholars played a tremendously influential role in selectively identifying music as folk/traditional/ancient, selectively valuing certain forms of musical expression according to their own aesthetics and agendas, selectively determining criteria for authenticity, and selectively canonizing and promoting historical music for public dissemination and education.

Particularly in Western Europe and North America, late nineteenth-century and early twentieth-century folklorists thereby played an important role in laying the groundwork for many folk revivals (for examples see Haines, Hill, Keegan-Phipps and Winter, and Sweers, this 
volume). And yet, at the same time, folklorists often dismissed and devalued revival processes and revival cultures as inauthentic and therefore unworthy of academic study or governmental funding, with clear demarcations being drawn between so-called revivalists and traditional folk artists, source musicians, or primary culture-bearers (see Conlon, Jabbour, Rosenberg, and Shay, this volume, as well as Rosenberg 1991 and Titon 1993). This delegitimizing of revival culture is best epitomized by folklorist Richard M. Dorson's (1950) distinction between folklore and "fakelore" - a term that is still occasionally employed in the early twenty-first century by scholars who wish to distinguish between what they perceive to be authentic and inauthentic folk music.

Meanwhile, in the field of anthropology, Anthony Wallace (1956) proposed a seminal theory of revitalization movements, of which he considered revival movements to be one subset. Influenced by structuralist-functionalist paradigms, he viewed revitalization movements as the means for a cultural system responding to stress to bring about necessary changes (which may be inspired by the past, and/or borrowed from other cultures or invented anew) in order to reach a “new steady state.” Many aspects of Wallace's theory remain applicable, including his emphasis on revitalization movements as "deliberate, conscious, organized efforts by members of a society to create a more satisfying culture" (279), and his critical awareness that "avowedly revival movements are never entirely what they claim to be, for the image of the ancient culture to be revived is distorted by historical ignorance and by the presence of imported and innovative elements" (276). Where Wallace's theory falls short, in retrospect, is in his functionalist view of culture as a holistic organism-like system, which fails to account for the formation of the myriad subcultures and transnational affinity groups that have increasingly characterized revival cultures from the 1960s onwards. 
Changing trends in academia very gradually acquiesced in accepting revival as a legitimate subject of study. Scholars in the field of folklore and, more particularly, the newer field of ethnomusicology (itself increasingly influenced by anthropology, especially in the wake of Merriam's The Anthropology of Music [1964]) began to focus less on the collection of authentic texts and more on cultural processes and contexts. The study of popular culture gradually became more respected. Philip Bohlman's The Study of Folk Music in the Modern World (1988) and Mark Slobin's Subcultural Sounds: Micromusics of the West (1993) served to validate contemporary manifestations of folk and traditional music in the Western world as legitimate objects for investigation alongside the living traditions of more distant cultures that had long been the prime territory of ethnomusicology. As self-reflexive and subjective scholarship gained prominence, and as former revivalists from the folk booms of the 1960s achieved secure academic positions, several revivalist-scholars wrote about their own first-hand experiences (see e.g., Rosenberg 1993, and Jabbour, Rosenberg, and Shay, this volume).

A groundbreaking work by historians was influential in refocusing the scholarly lens on the traditions of modern society. Closely related to the concept of revivals, Hobsbawm proposed the concept of "invented tradition", which was applied to deconstructing the nationalist rituals of modern nation-states. Asserting that “'traditions' which appear or claim to be old are often quite recent in origin and sometimes invented" (1983: 1), Hobsbawm argued that, "insofar as there is such reference to a historic past, the peculiarity of 'invented' traditions is that the continuity with it is largely factitious. In short, they are responses to novel situations which take the form of reference to old situations, or which establish their own past by quasi-obligatory repetition" (2). ${ }^{1}$ Frequently cited in literature on cultural phenomena that would fall under our definition of music revival, the discourse on invented traditions reflects a broader intellectual trend towards 
deconstructionism and cultural criticism ascending in the 1980s and 1990s (perhaps spurred on by postmodern disillusionment with grand narratives and the fall from grace of absolute truths, now decentered by the postcolonial multiplicity of previously subaltern voices). Charles Briggs went on to present an important critique of scholars who, in employing analyses of invented traditions, delegitimize culturally meaningful practices by pointing out historical discontinuities. Holding "the power to confer a sense of historical presence on some forms and withhold it from others," scholars of invented tradition thus become "arbiters of cultural genuineness, akin to the way that folklorists claimed the authority to distinguish the traditional from the modern —or ... ‘folklore' from 'fakelore”” (Briggs 1996: 460). These reservations notwithstanding, deconstructing the invented histories of revived traditions is still a vital tool in understanding revival processes and concomitant plays of power.

The latter half of the twentieth century saw a dramatic increase in scholarship on music revivals. Matching the trend towards particularism in post-Cantometrics ethnomusicology, ${ }^{2}$ most of these publications chronicle and interpret, through ethnographic or historical methods, the revivals of specific music cultures. ${ }^{3}$ Important theoretical groundwork was laid in two collections of essays, Transforming Tradition on the North American folk music revivals of the 1950s and 1960s (Rosenberg 1993) and a special issue of the World of Music journal entitled "Folk Music Revival in Europe" (Fujie 1996). Both volumes exemplify, in their respective case studies, how the process of reviving a tradition leads to transformations, how tensions arise between preservation and innovation, and how authenticity is invoked and manipulated. As many of the contributing authors to Transforming Tradition were themselves participants in revival activities, they offer important insights into the role of scholars and public folklorists as revival agents. (Four authors from these collections, Blaustein, Jabbour, Ronström, and Rosenberg, add further 
reflections in this volume.) Offering a more critical stance on revival agents, Benjamin Filene (2000) reveals the crucial, but often hidden, role that middlemen and cultural brokers play in manipulating academia, government institutions, and the music industry — the modern power structures for disseminating revivalist ideology. ${ }^{4}$

A seminal theoretical model on music revivals was presented by Tamara Livingston (1999). Synthesizing the existing literature on European and American folk and early music revivals, and drawing from her own research on choro revival in Brazil, Livingston defined revivals as "social movements which strive to 'restore' a musical system believed to be disappearing or completely relegated to the past for the benefit of contemporary society" (66). She emphasized the activist nature of revivals, asserting that

Revivalists position themselves in opposition to aspects of the contemporary cultural mainstream, align themselves with a particular historical lineage, and offer a cultural alternative in which legitimacy is grounded in reference to authenticity and historical fidelity. (Ibid.: 66)

She also offered a recipe of ingredients common to most revival movements, including core catalysts, original sources, an ideology and discourse, a community of followers, organized activities, and supporting industries (ibid.: 69). Her model—which she reviews and builds on in her contribution to the present collection—has provided a useful frame of reference for many of the authors in this volume.

$<2>$ Rethinking Revival in the Twenty-first Century 
Central to our motivation in planning this volume was the desire to fill gaps that we perceived in the existing literature and expand the general theoretical discourse on music revivals. These gaps, and the opportunities to forge new pathways that they opened up, became particularly apparent to us when we participated in the $38^{\text {th }}$ World Congress of the International Council for Traditional Music in Sheffield, England, in 2005, for which one of the themes was "Reviving, Reconstructing, and Revitalizing Music and Dance." Most prominent among the areas we felt were ripe for further exploration were the theorizing of authenticity, the documentation and explication of recontextualization processes, and, in particular, the conceptualization of postrevival, together with more detailed research into the ongoing impacts that are the legacy of revival movements. We were also aware of a wealth of fascinating and original work on contemporary trends that were not articulated in terms of revival but might nonetheless offer productive insights if viewed through the revival lens. Revivalist ideologies in North America and Western Europe may have tended, as Livingston suggests, to be "constructed on certain modes of thinking and structuring of experience that are shared by middle class people in consumer-capitalist and socialist societies" (1999: 66), but this is only part of the story. One of our objectives has been to explore the nature of ideologies of renewal and reclamation in other parts of the world, constructed in the language of different philosophical and ontological lineages.

The most obvious limitation of the extant English language literature on music revivals is, of course, its geographical coverage. The vast majority of work has focused on Western Europe and North America, with a smaller body of work on Eastern Europe and Latin America. ${ }^{5}$ The present volume attempts to rectify this imbalance with chapters on the Middle East 
(Nooshin, Shay), Central Asia (Merchant), South Asia (Walker), Southeast Asia (Howard, Norton), Indonesia (Kartomi), the Pacific (Moulin), Latin America (Gallaugher, Milstein), Africa (Muller, Neveau Kringelbach), and indigenous North America (Conlon, Levine). As part of the project of extending the revival concept to fit a broader variety of socio-cultural contexts, many of these authors offer their own definitions and interpretations.

In seeking to cast the revival net wider, we have embraced phenomena that may not have been defined in emic terms as revival movements, but nonetheless entail processes of retrieval, reconstruction, and recontextualization of the past to serve present purposes. In this sense, Livington's model, with its emphasis on the oppositional character of revivals, might best be viewed not as definitive but rather as one metaphor ("revival as social movement") among others. Alternative metaphors pursued by some of our contributors include revival as cultural rescue (Gallaugher), revival as therapy for trauma and recovery from the devastation of war or disaster (Ceribašić, Kartomi), and revival as assertion of indigenous culture following the lifting of former colonial oppression (Bithell, Conlon, Helbig, Levine, Neveu Kringelbach, Norton). Many of our chapters further refocus the revival lens on technological, economic, and institutional phenomena that have increasingly impacted the way revived musics are experienced in the late twentieth and early twenty-first centuries. These include, for example, the prominent part now played by commercial media (Moulin), the Internet (Blaustein), festivals (Helbig, Keegan-Phipps and Winter), academies (Hill, Merchant), national governments (Howard, Neveau Kringelbach), and UNESCO's policies regarding Masterpieces of the Oral and Intangible Cultural Heritage of Humanity (Bithell, Norton). We also expand revival theories in our encompassing of global trajectories, from diaspora and exile (Muller, Williams) to transethnic and transnational affinities (Bithell, Conlon, Shay). In the following sections, we discuss a 
set of themes and issues that remain crucial to our understanding of all of these variegated manifestations of revival.

$<1>$ Motivations: Revival as Activism

We may assume that musicians and other agents of revival always have a reason for wanting to perform, promote, or disseminate music from the past. While it is possible that this motive may be aesthetic, in the majority of cases there are clear (if sometimes unspoken) agendas linked to contemporary social, cultural, and/or political circumstances. ${ }^{6}$ The activist nature of revival efforts has been acknowledged as one of the defining characteristics of revivals throughout the history of their documentation, from Wallace's recognition of revitalization movements as deliberate, organized efforts by dissatisfied members of a society under stress to construct a more satisfying cultural habitat (1956: 265), to Livingston's identification of the main purpose of revivals as being to improve existing culture and/or serve as an alternative to mainstream society (1999: 68). ${ }^{7}$ Ronström (this volume) goes so far as to proclaim that revivals are "a missionary and a visionary phenomenon: there are revivals not because there has been a past, but because there is a future to come." This missionizing quality is reflected in the fact that many revivals are driven by impassioned and committed individuals—-Wallace's "charismatic leaders" and Ronström's "burning souls." The pivotal role played by such figures is evident in many of the case studies that follow (see e.g., Bithell, Conlon, Hill, Levine, Milstein, Nooshin).

Reflecting on revival activity around the world during the nineteenth and twentieth centuries, we suggest four general motivational categories (allowing that any given revival movement may have motives from more than one category). The first is related to a 
dissatisfaction with aspects of the modern world, variously expressed as anti-modernization, anti-industrialization, anti-urbanization, anti-secularization, anti-technology, anticommercialization, anti-consumerism, anti-capitalism, anti-mass media, or antiinstitutionalization. Modernity — that place where, as Marx put it, "all that is solid melts into air" — may be viewed as a distortion or deviation from the "natural" path, leading not to new horizons of unlimited opportunity but to alienation and confusion. Revivalist rhetoric in these cases may, for example, bemoan the depersonalization, ethical or moral degradation, or existential meaninglessness of contemporary society. Representations of the past—often romanticized, sometimes imaginary, and always selective — frequently evoke positive images of community-oriented interpersonal relationships, unmediated and noncommercial musical expression, pre-modern simplicity or innocence, pastoral tranquility, or the nobility of the peasant (for examples, see Haines, Helbig, this volume, Linn 1994: 116-179, and Boissevain 1992). In such revivals, it is not uncommon to see revivalist activities that prioritize participatory music-making, face-to-face interaction, community building, self-expression, and/or creativity. These kinds of activities may also prove attractive to classically trained musicians who welcome the opportunity to be free of the stylistic constraints of the classical orthodoxy and its often authoritarian, competitive ethos.

The second broad category in this generalizing typology of revival motivations is the bolstering of the identity of an ethnic group, minority group, or nation, which is often coupled with a distancing from, or othering of, foreign ethnic or cultural elements. The primary sociohistorical contexts for these motives are instances of nation-building, independence struggles and newly independent states, anti-colonial struggles and postcolonial aftermath, and civil rights and minority pride movements. Identity bolstering motives may also be linked to xenophobia, 
reactionary stances against immigration, or perceived threats from foreign influences, including imperialism, Westernization, or globalization. On one hand, exalting the professedly ancient heritage of a specific ethnic group or nation may be a strategy for demonstrating, to oneself and the international community, the worthiness and validity of the group. The classic example of this is the plethora of narrative sung poetry that, during the period of heightened European nationalism in the late eighteenth and nineteenth centuries, was compiled from peasants or historical sources, edited, and promoted with implicit or direct comparisons to the exalted Homeric poetry of ancient Greece (see Hill, this volume, and Wilson 1976). Bithell, Howard, and Norton (this volume) demonstrate the continuation of such processes of establishing international recognition of cultural value through the appointment of artistic practices and artefacts to UNESCO's lists of Intangible Cultural Heritage. On the other hand, revivals may be motivated by the desire to restore some sort of ethnic purity or demarcation, as exemplified in this volume's chapters on war-torn Croatia (Ceribašić) and the disputed ethnic ownership of Transylvanian traditions (Quigley). Both ancientness and ethnic purity or cultural uniqueness are often emphasized in revivals in newly independent nations, as evidenced in postcolonial India (Walker) and post-Soviet states such as Uzbekistan, Ukraine, Georgia, and Latvia (see Merchant, Helbig, Bithell, and Sweers, respectively). Continuing associations of folk music with ethnic purity demonstrate how the legacy of eighteenth-century romantic nationalist myths of folk music as the soul of a nation continue to shape twentieth and twenty-first-century ideology.

The third general type of motive for revival efforts is political. Revival activities have been employed for both left-wing and right-wing purposes, by both governments and protesters. The best documented cases have been grass-roots revivals in North America in the service of socialist, communist, labor, and civil rights movements (see e.g. Cohen 2002, Denisoff 1971, 
Eyerman and Jamison 1998, Filene 2000, Lieberman 1995, Reuss and Reuss 2000, and Weissman 2005); other work has focused on state-sponsored socialism and communism in Eastern Europe (see Buchanan 2006, Olson 2004, Porter 1997, Rice 1994, and Slobin 1996). In some cases, traditional music is invoked simultaneously by both the ruling regime and its contesters (see Howard, this volume).

The fourth motive is a practical response to natural or human disasters, as a result of which musical and other cultural practices have been torn away rather than abandoned or evolved. Such was the case in Afghanistan, for example, following the years of violent repression by the Taliban and in Cambodia following the ravages wrought by the Khmer Rouge, both of which resulted not only in certain forms of musical expression being suppressed but in musicians themselves being imprisoned, deported, or killed. Natural disasters—such as the tsunami that devastated coastal areas across South Asia in 2004 or the earthquake in Haiti in 2010 - have likewise caused the deaths of many leading artists and teachers, the destruction of cultural infrastructures, and the displacement of whole communities. In such situations, the revival of musical and other artistic practices has played a vital role in both individual and collective recovery (see Ceribašić and Kartomi, this volume).

Why, then, is music from the past an effective means of activism? The answer lies in part in the recognition that the past is not only a source of inspiration, but also a source of legitimacy (or occasionally healing). As Hobsbawm asserts, "what [tradition] does is to give any desired change (or resistance to innovation) the sanction of precedent, social continuity and natural law as expressed in history" (Hobsbawm 1983: 2). If the activist efforts of revivalists are successful, they may then lead to new subcultures or alterations to the mainstream, as discussed later in this 
chapter. Next, however, we turn to a more general consideration of the significance of history and its representation.

$<1>$ The Mobilization of the Past and the Selective Use of History

Revivals, by definition, depend on some kind of relationship with the past. Most often they seek to reintroduce forgotten, abandoned, neglected, suppressed, or otherwise interrupted practices from the past into the present. They may also stem from a desire to restore the integrity of present practices that are seen to have lost some defining aspect of their original form or meaning. The past, however, far from being clear-cut, is a notoriously slippery entity whose invocation involves both conscious practical choices and strategic rhetorical maneuvers. Trends in the representation, mobilization, and contestation of the past have been widely theorized by historians, archaeologists, and anthropologists. As part of the postmodern turn, exponents of what became known as post-processual or interpretative archaeology embraced a notion of the past as subjective, fragmented, malleable, multidimensional, and multivalent (see e.g., Hodder et al 1995 and Ucko 1995). Conceived in these terms, the past offers what musicologist John Butt has referred to as "an infinity of different worlds" (2002: 17), together with a treasure-trove of cultural symbols that may be adapted to many different uses and functions in the present. Here we wish to highlight three themes in the deconstruction of the past: the ideologically contingent and selective nature of received (or imagined) histories, the symbolic potential of the past, and the dynamic tensions to which competing interpretations of the past may give rise.

Different perceptions of history may shape both the rhetoric and actions of revivalists. Jabbour (this volume) observes that "people often see the past as more stable and unchanging, 
and the present as more dynamic and changing," imagining history as linear progress, like a jet plane taking off. In contrast, Jabbour posits, if we view history as cyclical, oscillating, and meandering, then revivals may be viewed as a natural part of culture's ebb and flow. A somewhat parallel view is common amongst some Native American peoples who, as described by Levine (this volume), consider history to be cyclical and view what we have defined as revival processes as the periods of sleep and wakefulness that cultural expressions undergo.

Regardless of their meta-views of the nature of history, revivalists are typically united by their adherence to a "received history" (Boyes 1993: xi). Stories about the past are rarely heard first-hand. They are most often passed down and, in the process, undergo a series of refinements: corrections are made and new errors introduced, facts are forgotten and elaborations added, inconvenient details are erased and rough edges smoothed off. The gaps left by memory and documentation (which by their nature can never be complete) are filled in by educated guesses, assumptions, and imaginative leaps. The "history" that results is highly selective—at best a partial truth — and continues to be molded by its interpreters, but it is this version of the past that then becomes part of the collective memory. ${ }^{9}$ Burt Feintuch even suggests that we might view revivals themselves as forms of memory, "loaded with the ambiguities that memory presents" (2006: 14). Revivalists, then, are active agents in reinterpreting, modifying, and forging new histories.

The Past in Music, a special issue of the journal Ethnomusicology Forum, was inspired by the guiding principle that "musical practices in the present are shaped not only by past experience but also by ideas, feelings and beliefs about the past" (Bithell 2006: 4). Its contributors built on the notion of the past as symbolic resource in exploring the ways in which music can be harnessed not only to invoke but also to transform the past. ${ }^{10}$ The act of 
reimagining or reinventing the past assumes particular prominence in the case of revival initiatives with a strongly countercultural character that look to the past to compensate for the shortcomings of the present as described in the previous section. Music genres associated with a supposedly simpler, purer way of life untainted by "progress" become a doorway into this quasimythic past-as-refuge. Transported into the present, the revived elements-like those of the nativistic movements described by Linton—serve as "symbols of a period when the society was free or, in retrospect, happy or great" (1943: 233). Revivalists, then, are concerned not simply with "the music itself" but also - or even more — with the projected values and partly imagined lifestyles they associate with it. In setting out to regain Paradise, revivalists embrace the music of the past as an act of "non-violent resistance" to modernity (DeTurk and Poulin 1967: 22) —a perspective that chimes with Svetlana Boym's theoriziation of nostalgia as not only a longing for lost dreams or for times and places that have slipped beyond our reach but also a "rebellion against the modern idea of time, the time of history and progress" (2001: xv).

The attraction of the past, then, rests not so much on what it was actually like, in a literal sense, but on what it has come to represent and how it may be used to justify action in the present. As Ronström expresses it: "Revival is only partly about 'what once was'. More importantly, it is about 'what is' and 'what is to come'.... In essence revival is a process of traditionalisation that goes on in the present, to create symbolic ties to the past, for reasons of the future" (1996: 18). Several of the case studies in this volume illustrate the ways in which the past is selectively employed, manipulated, and at times even fabricated to add legitimacy to choices made in the present, to challenge established orthodoxies, or to dispute claims to particular histories or traditions (see especially Hill and Walker). In some instances, revival performances may be more convincing to contemporary audiences for being based on imaginary histories (see 
Shay, this volume, and Taruskin 1982). Indeed, Lowenthal proposes that "heritage the world over not only tolerates but thrives on and even requires historical error" (1998: 132; see also Norton, this volume)

Of course, not all revivalists are converts to postmodernism and metaphor. Some believe that they know what the past was really like and seek to replicate past practices as accurately as possible. They might base their reconstructions on surviving memoirs or iconographic evidence whose accuracy or legitimacy goes unchallenged, seeing the precision of the reproduction as a measure of authenticity. Those who adopt this more fundamentalist and essentializing stance may come into conflict with those who take up a comparatively progressive position that allows for a more creative refashioning and that acknowledges the part played by present need. Niall Mackinnon's distinction between reviving and re-enacting is helpful here. A re-enactment requires "a suspension of the present, allowing the past to be entered into, but in a bounded sense," whereas in the case of revival (as Mackinnon defines it) the past is entered in a more symbolic way that "allows continuity through a process of artistic evolution" (1993: 7).

As communication systems, markets, and modern transport systems have brought ever more distant parts of the planet within reach, world music—or other people's folk music — has to some extent replaced autochthonous folk traditions in offering an alternative to the mainstream. Nostalgia for a more wholesome time and place may now be projected onto someone else's present rather than one's own past, and the desire to take refuge in a simpler, purer world may now be fulfilled by stepping sideways into contemporary societies elsewhere in the world rather than backwards into a less than tangible past (see Bithell and Williams, this volume, and Laušević 2007). This sideways step corresponds to Wallace's second "choice of identification"-importation — which he envisages as a parallel choice available to revitalization 
initiatives alongside revival with its retrospective orientation. Both strategies may be seen to share, however, a similar psychological underpinning. Importation may also result not merely in a one-way borrowing but in mutual exchange or collaboration, in which case it may give rise to the kinds of musical production that we depict as belonging to the post-revival stage.

$<1>$ Recontextualisation and Transformation

Some degree of recontextualization, whether intentional or circumstantial, is inherent in the very concept of revival. Ronström (this volume) suggests that we conceptualize revival processes "as shifts between different historic, geographic, social, and cultural contexts, between the individual and collective, private and public, informal and formal, and between different mythical geographies." "Shift" is useful in furnishing us with a comparatively neutral, depoliticized concept that is suggestive as much of a natural process as of individual intention or institutional strategy. Strictly speaking, recontextualization takes place each time a song, tune, dance, or story passes to a new exponent, even if it is often masked by a conceptualization of the performer as a faceless conduit of tradition, together with a lack of recognition of the crucial role of individual variation in many oral traditions. In other cases, the act of recontextualization is more blatant or dramatic, and it is shifts of this order that most concern us here.

Let us begin by considering the revivalists themselves. As many commentators have observed, revivals are often set in motion by individuals or clearly defined groups who are partial outsiders to the chosen tradition rather than core culture-bearers. Hence the much-remarked paradox at the heart of the North American folk revival of the late 1950s and 1960s, whereby young, white, middle-class, educated city-dwellers championed and appropriated for themselves 
the cultural practices of older, black as well as white, working class, illiterate farmhands, miners, and industrial workers. Examples from this volume include Native American musicians switching from Western band and jazz music to the traditional Native flute (Conlon), conservatory students brought up in Western classical music becoming Finnish folk musicians (Hill), British choirs learning to sing Georgian polyphony (Bithell), Americans adopting Irish and Iranian traditions (Williams, Shay), and revivalists re-infusing their own lost traditions with material from neighboring regions or tribes (Quigley, Levine). Even if they come from the same region, ethnicity, and class, the first generation of performers of a revived tradition are usually relative outsiders in the sense of having been raised in different musical idioms and environments before adopting the revived tradition. Shifts such as these have sometimes led to the line being drawn between "genuine" inheritors of a tradition and "revivalists" (as described earlier in this chapter). New converts inevitably adapt the music they discover to their own stylistic preferences and performance conventions, at times unconsciously. In some cases, they purposely strive to "improve" the tradition (a practice common especially in romantic nationalist and Soviet revival efforts). Some incorporate further influences from other sources, resulting in new hybrid styles, for which Ellen Stekert (1966) proposed the label "new aesthetic". ${ }^{11}$ What is most interesting about these shifts, from a critical perspective, is not the question of legitimacy as much as the reasons why they happen, what they reveal about broader psycho-social processes, and what part they play in the subsequent directions taken by spin-off and roots-based popular music genres.

Dividing lines between traditionalists and revivalists, or insiders and outsiders, have a pernicious quality and should not be taken at face value. As many of the case studies gathered here show, the reality is often closer to a continuum than to two sides of a coin. This becomes 
especially clear when we consider the contemporary generation, where many of those who are successful on the global music scene - armed with a diary packed full of concert and festival dates, and with strings of albums and awards to their credit - are the children or grandchildren of those who were counted among the "true" guardians and inheritors of the art form and rarely strayed far from home. These younger pioneers may, at some point on their journey, have helped to drive a revival movement. At the same time, they themselves grew up "in the tradition" and we may even find the voices of their younger selves in archival collections of ethnographic field recordings. Where they differ from their forebears is in the opportunities that were available to them: the world itself had changed. ${ }^{12}$

The notion of a continuum, meanwhile, is suggestive of a quasi-evolutionary process that might be construed as a straight line leading from past to future and this, too, is misleading. Often, as many of our case studies illustrate, different individual identities, stances toward tradition, and ways of being with music co-exist (see especially the chapters by Conlon and Milstein). In some cases, we see the same musicians behaving in different ways in different contexts and maintaining seemingly divergent styles and repertoires in parallel. In others, we see different individuals or lineages drawing from the same musical well but operating in different contexts, or interpreting and taking forward the same traditions in different ways, and some of these pathways may be contemporaneous from the outset. Of relevance here is Max Peter Baumann's model, which distinguishes between "those who define folk music traditions within the concepts of purism (with a tendency towards stabilizing or even regressive preservation) and of syncretism (with a tendency towards reinventing the past by emancipatory creation to the point of breaking the local and regional frontiers)" (1996: 80). These definitions clearly relate to other differences, such as in the positions adopted with regard to the interpretation of the past on 
the one hand and the role of the artist on the other. Here we might most readily think in terms of a spectrum with its suggestion of gradations between two extreme positions, or alternatively—as we move closer to the notion of post-revival — sectors of a circle where the shared point of reference is the seed, or question, at the center but where there is no attempt to establish a hierarchy in the diversity of responses.

Let us now turn our attention to the environment in which a genre or practice targeted for revival is performed. In the folk music revival archetype, one of the first acts of recontextualization is often a shift from the fireside, barn, village square, or other intimate location where friends and neighbors gather to make music and dance, to the concert stage, where the performer is clearly distinguished from the rest of the company, who are now assigned to the role of audience. This shift from—-to adopt Thomas Turino's (2008) terminologyparticipatory to presentational performance has many ramifications. It demands a degree of organization: a date is set, the event is publicized, and tickets are sold. The performance thus becomes a transaction: money changes hands and expectations are set up. This in turn might inspire some adjustments on the part of the performer. Instrumental accompaniment may be added to songs that are more often sung a cappella. Intervals may be standardized so as to make the music sound more "in tune" to the modern ear. As performers become more accomplished, they may be eager to push the boundaries beyond traditional standards of artistry. As a next step, an artist may start to receive invitations to perform further afield and thus may assume a new role as cultural ambassador. In appearing at festivals, he or she may be exposed to different kinds of music and have the opportunity to exchanges tunes, stylistic approaches, and ideas about the meaning of tradition and the role of the performer. Some of these influences will be taken back 
to the home culture, where they will appear as innovations - perhaps framed positively as inspired advances or, more negatively, as departures from the tradition.

All of this is part of a gradual process of professionalization, institutionalization, commercialization, and commodification. Artists who continue on this path and become ever more cosmopolitan in their outlook may be accused of moving away from their roots or of selling out to fame and fortune. Performers themselves are often keenly aware of the tensions accompanying such a trajectory and struggle to find their own balance between faithfulness to, respect for, or continuity with "the tradition" and their right to pursue their own creative paths as autonomous artists. Some have argued that all traditions start somewhere, and there is no reason why what today seems like a new departure should not become the tradition of tomorrow. Here we may note Eyerman and Jamison's proposal (referencing Rosenberg 1993) that "what is at work in periods of recombination or transformation is both more creative than revival and less creative than invention. ... Musical traditions are ... made, and remade, in processes of mobilization" (1998: 38-39). At the same time, transformations wrought through revival efforts may open up alternative artistic pathways that provide opportunities for creativity not available in other idioms.

Mackinnon's category of re-enactment is again relevant here. Many of those who identify as traditional musicians would themselves argue that they are not aiming to, and should not be expected to, reproduce their music or dance exactly as it was at some putative point in the past. If this were the goal, then the result (this argument continues) would be nothing more than a museum piece. The notion that a tradition is fixed is in any case a fallacy. A tradition is always in movement and for something to continue as part of a healthy, living tradition it has to correspond with the needs and concerns of its own time. This rationale holds even greater sway 
if the performers in question are seeking to enlarge their audience or convert more followers to their cause. They may be promoting a form or practice that is marked as ancient, and the accompanying discourse may be rife with references to history and the past, but the product itself has to appear both relevant and palatable. In some cases, the argument that music has to change in order to survive might appear as little more than a rhetorical ploy to justify innovations that might otherwise be cast as more radical departures, but rhetoric is also what interests us here. Meanwhile, in some contexts (including the new Grammy Award categories, drastically modified in 2012) "roots" now serves as a catchall label embracing what may once have been juxtaposed as traditional and contemporary, or authentic and revivalist, and to some extent erases - albeit controversially — the thorny distinctions between them.

In other types of revivals, recontextualizations may follow different paths. In the process of reviving classical music and dance traditions, a (semi-)professional art form patronized by a small elite may be made available for the masses (see Nooshin, this volume). Sacred traditions may be transplanted from temples to secular institutions (see Walker, this volume). A professionalized, commercialized recorded music may be transformed through revival into a participatory folk tradition, as happened in the bluegrass revival (see Rosenberg 1985).

In the process of these various repositionings, many transformations take place: in aesthetic norms and tastes, in the relationship between performer and audience, in the creative dialogue between the performer and the musical raw materials, in the aspirations of the individual artist, in performance contexts and locations, in the functions and meanings attached to the music and its performance, and in broader rationalizations about the place of music in society and the nature of tradition in the modern world. The theme of revival as transformation surfaces often in the literature: see, for example, Burt Feintuch's chapter "Musical Revival as 
Musical Transformation" that provided the inspiration for the title of the collection Transforming Tradition (1993). In some ways, the "trans" prefix — transition, translation, transubstantiation, transportation, transformation —is helpful in letting us off the "re" hook (see Slobin, this volume) and giving us more positive endorsement to face forwards rather than backwards.

Transformation is often linked conceptually with innovation while innovation continues to be juxtaposed to tradition, as suggested by the titles Transforming Folk: Innovation and Tradition in English Folk-rock Music (Burns 2012) and Indigenous Popular Music in North America: Continuations and Innovations (Neuenfeldt 2002). Innovation is nonetheless worthy of investigation in its own right. Milstein (this volume) suggests that "revival currents, as distinguished from movements, open avenues for innovation rather than recycling practices or re-creating a fictitious past." Yet recycling pre-existing material in new ways—one of the most fundamental creative techniques (see Boden 2004 and Lessig 2004, 2008) — is a common means for the renewal of music cultures. Innovation processes that directly manipulate historical material, or that more loosely draw inspiration from imagined pasts, are fundamental components of revival (see especially Conlon and Hill, this volume). Such transformations may relate to the musical fabric - the music itself—or may be at the level of new uses and functions, new contexts and meanings, new cultural infrastructures, new markets and means of dissemination. Of course, some aspects may be renewed while others stay the same or even revert to an earlier form, and critical observers may be more alert to these nuances than those closer to the tradition's epicenter (see Sweers, this volume). Other dynamics are at work in diasporic situations where musical practices in the new homeland may be preserved in a form closer to how the tradition used to be in the world that was left behind. While the geographical displacement may be monumental, the temporal displacement may be on an entirely different 
scale. Time may be slowed down in comparison with the homeland, such that more "ancient" practices are preserved in the new location while, in the original location, the tradition has moved on. Perhaps the most important point to underline here is that transformations are never monolithic: they are not a neatly choreographed affair where everyone moves in the same direction at the same time.

$<1>$ Authenticity, Authority, and Legitimacy

As recontextualizations engender transformations in sound, practice, and context, the new generation of performers (whether technically "outsiders" or not) are left vulnerable to having their right to be bearers and innovators of a tradition questioned. There are numerous examples of scholars, government policy-makers, and even revival artists themselves doubting or denying the legitimacy of revivalists and their music. As discussed above, folklore scholarship has a long history of dismissing revivalists. In musicological discourse, debates about authenticity in the early music revival have been extremely heated, particularly regarding with what authority modern performers interpret historical music, as exemplified in Taruskin's article "The Authenticity Movement Can Become a Positivistic Purgatory, Literalist and Dehumanizing" (1984) (see also Leech-Wilkinson 2002, Morrow 1978, and Waitzman 1980). ${ }^{13}$ In relation to government policies, specific notions of authenticity may be employed to judge which types of musicians are deemed worthy of recognition and support as National Heritage Fellows or Living Human Treasures and which are not (see Conlon, Howard, and Jabbour, this volume, and Titon 1993). Some revival artists may feel themselves unauthorized and censor their own creativity. 
Others may feel frustrated, defensive, or defiant in the face of others' judgments of their authenticity (see Shay, this volume).

Thus, establishing authenticity is often a crucial act if revival artists are to gain acceptance and respect for themselves and their music. In instances in which revivalists are striving to achieve an activist agenda or to establish a viable alternative to the mainstream, conferring authenticity can also be a useful strategy for obtaining support and acceptance for change. In such cases, the evocation of the past may help to disguise change and innovation as conservativism and preservation (see, for example, Hill, Shay, and Walker, this volume).

In nearly every instance of revival, then, authenticity is invoked, and frequently hotly contested. Often, however, artists and scholars alike have been guilty of conflating the definition of authenticity with the idealized criteria used to establish authenticity. As Weisethaunet and Lindberg observe, while authenticity may be perceived by academics as a quality ascribed to representations, most others take it literally as an essence inherent in an object (2010: 465-466). According to the Oxford English Dictionary, the terms authentic and authenticity invoke a sense of genuineness, "being true in substance," and "being what it professes to be in terms of origin or authorship." Additionally, and significantly, they also carry the meanings of being authoritative, valid, and "of established credit," as well as being "entitled to acceptance or belief," and, in the original 1340 usage, "entitled to obedience or respect." In sum, the label "authentic" expresses a triple meaning: genuine, authoritative, and deserving of our credence. Successfully and convincingly wielding this label thus has the potential to confer power and legitimacy. The process of establishing authenticity begins with the highly selective and subjective identification of particular aspects or elements in a music-culture, followed by the decision that they should be perpetuated and the assertion of their value. These selections become ideals, models to strive 
towards, measures of assessment, and the criteria for establishing authenticity. In revivals, these idealized criteria are often historical—-though history may be reinterpreted, imagined, or selectively focused in order to emphasize criteria that resonate with contemporary interests. In popular music or the visual arts, other more contemporary criteria, such as authorship or selfexpression, may be more highly regarded. The agents who determine the criteria for authenticity may be scholars and collectors, producers and promoters, artists, or fans; conflicting assertions of authenticity amongst different parties are not uncommon (see Hill, Merchant, Shay, and Walker, this volume). ${ }^{14}$

The types of criteria upon which authenticity hinges vary widely according to cultural and historical context. The selection of ideals reflects shifting technology, political motives, and general intellectual leanings. ${ }^{15}$ Nevertheless, we have observed broad trends in what may be categorized as (1) product-oriented criteria, (2) person-oriented criteria, and (3) process-oriented criteria.

Product-oriented criteria encompass physical objects such as manuscripts, ephemeral objects such as songs, and sound products in both recordings and live performances. In notated traditions that venerate music as text, revival movements may prioritize repertoire and focus on composers' sketches and certain editions as authoritative. In orally transmitted traditions, the documentation of melodies and song lyrics into written notation before the advent of recording technology led to a high valuation of melodies and texts that were perceived to be the most traditional (epitomized in Anglo scholarship by the obsession with Child ballads). Increasing availability of audio recordings facilitated a focus on idealized sounds, such as timbre, accents, ornamentation, and other elements referred to as style, as well as production-related sounds, such as acoustic and unprocessed sound (see Rosenberg 1993: 12-13 and Feintuch 1993). The 
emphasis on period instruments, temperament, and intonation in the historically informed performance movement in Western art music also exemplifies sound product as authenticity criterion.

Person-oriented criteria comprise the traits of source musicians or communities, performers, and/or creators. One common trend is to idealize persons hailing from remote regions that are believed to have been isolated from some of the conditions that caused cultural change in the revivalists' population centers (e.g., industrialization, religious conversion, political revolutions, or economic development). ${ }^{16}$ Such cases discussed in this volume include Hungarian revivalists appropriating music from Romanian Transylvania (Quigley), Finnish revivalists collecting material from Russian Karelia (Hill), and French scholars researching songs in Québec (Haines). Age and education are other person-oriented criteria, employed especially by collectors in seeking out source musicians (see Sharp 1917 and Lord 1960, who both valued songs collected from older illiterate singers).

The most problematic and potentially insidious person-oriented criterion for authenticity is ethnicity, which stems largely from the blood-and-soil variety of nationalism. This is particularly relevant in revivals of folk music_-not surprisingly, as the term folk (or Volk) was coined by Johann Gottfried von Herder, whose widely disseminated propaganda about folksongs as the soul of a nation still influences the significance of folk music around the world. However, it may also be employed in other idioms, such as jazz. A prime illustration in this volume is Merchant's exposition of her informants' belief that tradition is in the blood and proficiency in Uzbek music is correlated with having Uzbek bloodlines.

A key contemporary arena in which person-oriented criteria are employed is in the contentious authentication of who owns tradition. Such debates often pivot between the aim to 
protect the heritage of certain ethnocultural groups (especially indigenous ones) from exploitation versus the desire for artists around the world to have access to traditional material in the public domain, regardless of their ethnic heritage, and not have their creativity limited by intellectual property restrictions (Brown 2003; see also McCann 2001, Mills 1996, and Zemp 1996). Communal ownership of a shared tradition may be relatively clear for an intimate and participatory music culture such as the Suya in the Amazon basin (Seeger 1992). However, when the concept of communal ownership is extended from localized networks of physically interactive and interrelated people to the imagined community of the nation, then there is a danger that the primary criterion for determining the authority of a tradition holder may be his or her ethnicity or nationality. As Brown (2003) warns, one group's urge to claim ownership of cultural goods may well obscure the creole nature of the goods themselves and deny similar rights to other groups that share the goods' collective history of creation and stewardship. This situation has created tense arguments in Hungary and Romania over the purity and ownership of musical heritage from ethnically diverse Transylvania (see Quigley, this volume). Issues become even more complicated when individuals shift their ethnic identification (Gallaugher, this volume) or when the ethnocultural boundaries of the group are extended or contracted into different configurations (see Hill 2007).

Much emic discourse about authenticity emphasizes purity, and in particular ethnic purity. These ideals are especially prominent in the initial stages of postcolonial, postindependence, and postwar situations, as demonstrated here by chapters on India (Walker), Ukraine (Helbig), Uzbekistan (Merchant), and Vietnam (Norton). The use of ethnic criteria in establishing and contesting claims to particular musical genres or instruments came to the fore especially strongly in the context of the Balkan wars of the 1990s (see Longinovic 2000, Pettan 
1998, and Ceribašić, this volume). In the process of claiming ethnic purity, however, intercultural influences are frequently underplayed (see Helbig, Norton, and Walker).

Conversely, a small but growing trend has been to herald hybridity as a criterion of authenticity (see Gallaugher and Levine, this volume, and Taylor 2007). ${ }^{17}$ Meanwhile, in cases in which musicians participate in the performance of traditions originating from other ethnic groups, these ethnic "outsiders" must find other ways of asserting their authority as performers (see Bithell, Conlon, and Williams, this volume).

If the essentializing tendencies of person-oriented authentication are at their most extreme in the case of ethnicity, similar processes of authentication may also apply to other criteria, and here, too, they are laden with unequal power dynamics. Several chapters in this collection illustrate the continuation of different plays of power, whether in relation to gender inequalities (Conlon, Helbig, and Walker), racism and xenophobia (Blaustein and Ceribašić), or class inequalities (Blaustein, Howard, and Walker). Yet by the end of the twentieth century attitudes towards notions of purity and authenticity had shifted — albeit not globally—as certain restrictions imposed in the name of tradition could now, from the perspective of civil or human rights, be framed as discriminatory: sexist, racist, elitist, or imperialist. The desire to respect a people's culture balanced by the need to protect human rights have led to significant tensions, which, though rarely motivated by specifically musical concerns, have colored the climate in which public cultural displays take place. This has, in some cases, lent a different kind of legitimacy to those seeking to break through local restrictions.

While many of the person-oriented criteria discussed thus far are group centered, another important stream centers on the individual. Establishing individual authorship is one of the most important grounds for authentication in the art world (for example, establishing whether a 
particular painting really was painted by Van Gogh). Lineage may be another important means for individual artists to establish their authenticity (see Walker, this volume). Meanwhile, in Western art music, performers, conductors, and editors often vie to establish authority by invoking the composer's intentions - which Taruskin sees as another means of asserting personal authority (1992: 317).

A third commonly invoked category of authenticity criteria is process-oriented. This category includes transmission, creation, and reception. Historically, great emphasis has been placed on the circumstances of transmission for establishing the authenticity of both source musicians and revivalist performers and this continues to carry significant weight in many circles. Depending on the cultural context, oral transmission and guru-apprentice relationships have often been considered more valid than learning via books or institutions. (This value system is sometimes used to authenticate scholar-performers within the field of ethnomusicology—-for example, in assessing how ethnomusicologists achieve their "bimusical" credentials.) Institutionalized transmission has been relatively underplayed and understudied in ethnomusicological literature to date. In this volume, case studies by Hill, Merchant, and Quigley reveal some of the authentication strategies employed by academy musicians and institutions (see also Keegan-Phipps 2007).

Creative processes seem to have become a more highly valued index of authenticity since the latter third of the twentieth century, particularly in Western contexts. A general shift from product-oriented to creative process-oriented criteria may have been influenced by several factors. Albert Lord's (1960) groundbreaking work on oral composition encouraged folklore and classics scholars to focus on traditional creative processes around the world (see the journal Oral Tradition and, e.g., Pihl 1994 and Titon 1994). Since many folklore scholars were also engaged 
as agents of revival, this intellectual trend influenced revival activities as well (see Hill, this volume). Political protest song movements, such as those in the United States and in Latin America in the 1960s, foregrounded the composition of topical songs in folk-inspired styles in response to current events. Though later developing into less overtly political singer-songwriter genres, the emphasis on writing songs in response to life experiences has in many cases remained, and iconic role models such as Woody Guthrie, Pete Seeger, Victor Jara, and Silvio Rodríguez continue to be revered and emulated. Furthermore, Weisethaunet and Lindberg (2010) suggest that literature on the blues as an expression of deeply felt emotions influenced the development of expressing one's feelings as an important marker of authenticity in rock discourse. As many later revival generations were raised with rock as a part of their mainstream cultural environment, this valuation of personal expression has been carried back over into folk and traditional music.

Valuing creative process may entail concerted efforts to learn traditional musical vocabulary, forms, and syntax so that revivalist performers can compose and improvise in a traditional style, as in Ronström's (1998) description of the Swedish folk revival. It may entail the invention of a new method for the systematic generation of professedly traditional music, as in the development of the radif in Iran (Nooshin, this volume). Or it may be embraced in a more abstract valuation of individual and artistic expression, as in the Finnish ideal of embodying the creative folk spirit and synthesizing all of one's influences (both traditional and otherwise) into personal creations (Hill, this volume). Such emphasis on, and valuation of, musical process usually allows for greater degrees of individuality, artistic freedom, and innovation.

Revival activities oriented more towards innovation and creativity may be perceived by some as being less traditional or pure, as depicted in Baumann's (1996) model of purism versus 
syncretism as contrasting revival approaches. In effect, this is a case of conflicting authenticity criteria. Innovation, if pursued according to certain criteria, may be argued to be just as traditional and authentic as faithful replications of historical pieces. Indeed, in instances in which shifts have occurred from product-oriented to process-oriented approaches, the new generation of revivalists often attempt to delegitimize the earlier revivalists' authenticity markers: Ronström's description of this process in Sweden, for example, critiques earlier revivalists who "merely reproduce the collective leftovers stored in museums and archives" (1998: 40-41; see also Hill and Merchant, this volume, and Filene 2000: 183-232). Under other circumstances, as Livingston (1999: 80-81) notes, innovation may be an indicator that the revival has moved into a post-revival phase and historical authenticity is no longer an overriding concern. These trends chime with Feintuch's suggestion that "it works better to think of tradition as a territory of the imagination rather than as a standard for some notion of authenticity" (2006: 9).

The reception process is described by Ronström (this volume) as "the authenticity of the consumer": "The authentic is the experience, the taste, or the emotion. What is true is what feels true, a position explored by the growing experience industry.” To this we might add Weisethaunet and Lindberg's (2010) depiction of the "authenticity of experience" as a fan's ability to identify with someone else's musical expression or see themselves in a new light by listening to a piece of music. Here we focus more on the consumer's judgement of the performance and/or the performer. This layer of authenticity exists in a realm apart from the performer's understanding of authenticity. To some extent, it depends on expectation —an expectation that may be ill-informed, based on mythology, inherited prejudice, or manipulated by market forces. At its most mundane level it may focus on visible signs and symbols such as costume and, in the case of "folk" performances, baskets, floral wreaths, pitchforks, guns, or 
other such accoutrements. (See Shay, this volume, for examples of Orientalist expectations influencing Iranian artists; for more on the importance of visual symbols, see Helbig, Moulin, and Sweers, this volume.) The mismatch between consumer expectation and artistic intention (or contemporary reality) has been especially remarked upon with regard to world music artists from the African continent, who have often found themselves accused by Western audiences of inauthenticity for their failure to match an antiquated, colonial-flavored, and ultimately racist imagining of "Africa" as "primitive," "natural," and in other ways pre-modern-sometimes marked by a proliferation of drums and grass skirts. Timothy Taylor (1997) has used the term "strategic inauthenticity" to describe the stances adopted by artists such as Angélique Kidjo and Youssou N'Dour, who have insisted on their right to appear, and make music, as autonomous, creative artists and as citizens of a modern, cosmopolitan world. This stance relates to a broader discourse often adopted by artists at the more innovative end of the spectrum who speak of authenticity in terms of being true to one's own creative impulse, one's own life experience, and the concerns of one's own age or era. The conservatism or prejudices of some world music audiences notwithstanding, the international stage has been an important space for artists to create and explore away from the scrutiny and authenticity criteria of the home community.

$<1>$ Transmission, Dissemination, and Promotion

In order for a music revival to be successful, revivalists must publicize their selected tradition to new audiences and enable new performers to learn. The inevitable recontextualizations of traditions undergoing revival, whether temporal, geographical, or social, often lead to radical changes in the nature of transmission and dissemination. In folk music revivals, a fundamental 
shift frequently occurs from in-person, informal oral transmission to more deliberate, formalized, and often standardized methods, usually supported by new infrastructures. In almost all cases hereditary modes of transmission have to be modified because those of the revivalist generation have not grown up in the tradition and therefore need to be initiated in a way that allows them to bypass more organic, lifelong processes of acculturation and apprenticeship. New teaching and learning methods have to be found, especially if revival musicians do not have access to a community of primary culture-bearers or source practitioners. In some cases, this may be because the last generation of guardians of the tradition in its original habitat has already passed away, or because artists and teachers have been lost as a result of war or natural disaster. In considering transmission processes, Ronström's equation of revival to an act of translation suggests helpful perspectives. A translator does not set out to substantially change the original text, yet the new text he or she produces is rarely a literal, word-for-word translation: in order to make sense to the target reader, it has to involve some degree of reinterpretation informed by knowledge of the cultural context in which it will be received. In recent thinking in the field of literary translation, a distinction has been made between "cultural transfer" as a oneway activity (akin, perhaps, to transplantation) and "cultural transmission" as a reciprocal process that emphasizes the mediatory and pioneering role of the transmitter. ${ }^{18}$ In the case of revivals, transmitters always play a crucial role, whether the students with whom they are working are from a foreign culture or simply from a different social class or age set. Revivalists who have consciously learnt a tradition after being introduced to it later in life, as opposed to having been born into it, may be well positioned to undertake the role of transmitter, which, in addition to musicianship, demands a facility for pedagogical communication and the ability to 
explain the tradition to outsiders or newcomers. Source musicians may offer the best role models but they are not necessarily the best teachers and translators.

Proactive dissemination, via a range of media, may be required either to help draw in and train new converts or to bring the musical output of revivalists to a wider audience. In addition to the revivalists themselves, stakeholders may come to include record companies, music publishers, festival and tour organizers, and archives. Changes in the wider word have also influenced modes of dissemination. Many latter-day revival cultures have been strongly impacted by the spread of new media and technologies, the emergence of the world music industry, and trends in heritage conservation and cultural tourism.

The earliest method used by revivalist-collectors to disseminate their work and provide learning materials was to publish collections of musical notation, for example in national songbooks. In the process of rendering orally transmitted music into notation changes were inevitably introduced. Some of these changes have been the unconscious results of mishearing, the inadequacy of notation in capturing all dimensions of a performance, and the isolation and decontextualization of small segments of music from a larger whole. Other changes have been deliberate as collectors "corrected" texts and melodies to fit their own aesthetics or adapted them in ways that made them more suitable (in their eyes) for popular consumption. In order to encourage the widespread performance of the songs and tunes they collected revivalists have been known to simplify melodies by omitting ornamentation and variation, force them into standard time signatures and tonalities, and add what they perceived as more modern accompaniment. Such compromises often helped make the material more accessible to newcomers to the tradition, in some instances allowing it to spread like wildfire as acolytes 
eagerly added the latest new item to their personal repertoire (as in the case of the American publication Sing Out! whose circulation reached tens of thousands in the early 1960s).

As technologies developed, learning materials were made available in a variety of new media, beginning with audio recordings. While learning from audio recordings may reduce the changes brought about by the subjective process of transcription and the limitations of notation, and may be considered by some to be a form of oral transmission, it nevertheless introduces changes in transmission. The fact that learners are likely to listen to the same version of a piece over and over, for example, may lead to a loss of variation and a degree of standardization and homogenization.

The publication of revival materials in print and recorded forms has usually occurred alongside a new performance culture supported by dedicated infrastructures, such as record companies, folk clubs, and festivals. Record companies, distributors, and festivals that may have started out as grassroots initiatives have often become part of an established industry now firmly embedded in a capitalist economy and driven by other agendas (financial, regulatory, etc.). Promotion of the product itself is often accompanied by the dissemination of a discourse and rhetoric, via CD liner notes, concert programs, websites, and reviews, and this is one means by which received histories gain wider currency and claims to legitimacy are reinforced (see Conlon and Moulin, this volume). Some forms of promotion, such as competitions, may introduce further changes in performance practice via the rules they enforce (see Goertzen 1997).

Festivals and folk clubs have been important sites for newcomers to hear and meet their role models in person, as well as for networking and community building in general (see Blaustein and Quigley, this volume). Festivals also offer unprecedented opportunities for artists and promoters to showcase their products, and have been especially significant in bringing 
revived repertoires to the attention of ever more diverse audiences, including tourists (see Keegan-Phipps and Winter, this volume). Rebranding contemporary interpretations of folk music as world music, folk-rock, post-folk, nu-folk, or other trendier labels may extend their appeal to home audiences whose habitual comfort zone may be rock, jazz, indie singer-songwriter, or mainstream popular music, as well as to new international audiences for world music. Large festivals with multiple stages also allow for cross-programming and for casual encounters, on the part of festival-goers, with styles of music that they would not deliberately seek out. ${ }^{19}$

Opportunities for "foreign" enthusiasts to learn to perform music or dance from outside their own culture have also become more widespread. These include the participatory taster workshops included in many festival programs, intensive summer schools (often in the country of origin), and weekly classes in the student's own locality. Such cross-cultural transmission calls for teaching styles to be adapted to the new context and in some cases special teaching methodologies have been developed explicitly for non-native learners (see Bithell, Conlon, Shay, and Williams, this volume, and Solís 2004).

Other key locations for the transmission and dissemination of traditions-in-revival have been national institutions, including conservatoires. In many cases, the institutional support of previously marginalized idioms has been part of a broader official project to reconfigure national identity and history, following either independence from a former colonial power or radical regime change (see Merchant, Neveu Kringelbach, and Nooshin, this volume). In other cases (particularly in socialist and socialist-democratic countries), the adoption of a revived tradition into state-supported academies has been tied to a populist or socialist-oriented democratization of music culture by accommodating the "music of the people" in prestigious cultural spaces previously reserved for elite Western art music. In addition to training new generations of 
professional musicians and music teachers, the process of institutionalization has substantial impacts, which, to summarize briefly, may include professionalization, artification, standardization, homogenization, an imposition of Western art music pedagogy and values, the development of traditional music theories, status changes, the creation of new hierarchies, and the intensification and dissemination of certain value systems and ideological agendas. ${ }^{20}$

At the governmental level, policies of international bodies such as UNESCO have exerted increasing influence on national strategies for cultural promotion. Since 2001, traditional forms of expression from all parts of the world have been added to UNESCO's masterpiece proclamations and listings of intangible cultural heritage. In order to become a party to the 2003 Convention for the Safeguarding of the Intangible Cultural Heritage, a state must commit itself "to take the necessary measures to ensure the safeguarding of the intangible cultural heritage present in its territory" by compiling inventories and documentation, and by "endeavour[ing] to ensure the widest possible participation of those that create, maintain and transmit the heritage, and to involve them actively in its management" (UNESCO 2003). The many ramifications of UNESCO's interventions and related state policies are explored in the chapters by Bithell, Howard, and Norton.

In the twenty-first century, the Internet also serves as an important platform for both the dissemination of teaching materials and the creation of new networks, whose members may exchange materials and experiences, and even perform together, without ever meeting face-toface (see Blaustein, this volume). At this level, revival continues to thrive as a grassroots, bottom-up activity but its community is more likely to take the form of a scattered, transnational affinity group than a local collective or national subculture. This kind of community also 
partakes of the nature of diaspora - another feature of the postcolonial world that has assumed ever-greater prominence as theoretical tool as well as existential reality (see e.g., Gandhi 1998).

$<1>$ The Post-revival Turn: Revival Legacies

The kinds of shifts - recontextualizations, transformations, and innovations — summarized thus far inevitably introduce changes to a tradition and may result in a music or dance practice initially selected for revival evolving to a point where it has become something new that now enjoys an independent existence, free of its once symbiotic connection to a particular social, political, or aesthetic cause. The motivation behind the original revival impulse may in any case have lost much of its potency as the core revivalists have either achieved their objectives or moved on-whether to other causes or to new identities as independent performing artists in the commercial entertainment world. Spin-off traditions may also evolve in different directions as some of the original revivalists, or the next generation to whom they pass the baton, seek to break free from the restrictions imposed by the purist arm of the revival and develop practices more apropos to their own contemporary reality. Regardless of how progressive these changes may be, aspects of the revivalist discourse and value system nonetheless continue to carry influence (for examples, see Ceribašić, Conlon, Howard, and Milstein, this volume).

In other instances, the revived practices may undergo less radical shifts as they gradually settle into something akin to Wallace's (1956) "new steady state" (preceded, in Wallace's model for religious revitalization movements, by phases of "adaptation," "transformation," and "routinization"), and this may involve their adoption by the mainstream. They might undergo a process of classicalization or gentrification, in the course of which they are accommodated to the 
dominant musical discourse, or they might become "hip" in the eyes of a younger generation for whom retro is progressive. Alternatively, they may retain a more niche identity apart from the mainstream but with their future seemingly secure in the hands of a new subculture or affinity group. (For examples of various "new steady states", see Blaustein, Hill, Jabbour, and Quigley, this volume.) As they evolve, these revived traditions may become less bound to demands for legitimacy and stringent rules governing authenticity: compromises may be made or anxieties relaxed as broader horizons are glimpsed. The identities assumed by leading exponents may also change - for example, from cultural militant to cultural ambassador or creative artist.

Some commentators have referred to these developments in terms of a breakdown of the original revival. Ellen Koskoff, for instance, suggests that all revivals go through a period of boom and bust before they break down completely (2005: 69). Livingston also speaks in terms of "breakdown" in describing how the tension between preservation and conservation on one hand and creativity and innovation on the other can lead to a splintering of the revival community into fundamentalist and progressive factions. Is such breakdown inevitable and does it in fact equate to demise? If so, what fills the space that the revival vacates? Conversely, might a revival ever be said to be "never-ending," as the title of Michael Scully's (2008) book would have it? The new wave of resurgence in English folk music in the early twenty-first century was hailed by some as a third revival. Does this suggest a cycle that will simply go on and on, until we reach a tenth, a fiftieth, or a hundredth revival? Both Jabbour and Levine (this volume) explain revival phenomena as a recurring, cyclical process that is part of the natural ebb and flow of culture. Certainly the myriad manifestations of revival described in these collected essays demonstrate the universality of the appropriation and employment of the past as a tool commonly employed by humans to (re)shape their cultural environment in times of need. Nevertheless, for each surge 
of revival activity, logic suggests that there will come a time when a particular revival movement might be said to have either failed or succeeded. If a once-neglected genre has been safely reinstated and is no longer at risk of extinction, then it no longer makes sense to frame it in terms of revival. This is not, however, the end of the story. The question remains: what comes after revival?

Here we suggest a theoretical middle ground between the two poles of breakdown and never-ending revival, for which we adopt the notion of post-revival. A post-revival phase is characterized first and foremost by the recognition that a revived tradition has become firmly established in a new context where it can no longer be described as either moribund or threatened and is therefore no longer in need of rescue. This post-revival space may also be populated by spin-off genres and practices - the "new sounds, new textures, and new repertoires" for which the revival served as a catalyst (Livingston 1999: 81). Of course, the transition to a post-revival state is, in practice, a gradual process. Usually, there is no clear boundary between "revival" and "post-revival," and in some cases we might identify particular trends as having a post-revival quality while others remain rooted in a revivalist gestalt. As a concept, however, post-revival is especially useful for the way in which it allows us to acknowledge the significance of the original revival impulse and to identify a new musical or social culture as part of its legacy. Postrevival also recommends itself as an analytical tool because of the ways in which it resonates with other "posts": post-modern, post-industrial, post-colonial, post-national, post-ethnic — terms which color the ethnographic environments of many of the case studies in this volume.

"What comes after revival?" was precisely the question on the lips of many Corsican musicians as they recognized that the riacquistu (lit. reacquisition) set in motion in the 1970s had succeeded not only in reversing the decline to which traditional music had seemed to be 
condemned but in elevating it to an unprecedented position of prestige that coincided with its entry into the world music market-a circumstance that introduced new dilemmas and challenges, as captured in Jean-François Bernardini's trenchant observation that "to preserve what you have acquired is one thing, to give it a future is another" (cited in an edition of CorseMatin, 2000). For many late- or post-revival artists, the answer to the question "what next?" has lain in exploring their individual creativity alongside experimenting with a more eclectic palette of musical idioms, including influences from beyond their own culture. In explicitly drawing a line under the revival proper, musicians free themselves from the apron strings of "tradition," laying claim to their right to move forward in the same way that any artist who has never been cast as a spokesperson for a tradition is allowed to move forward, and inviting audiences to judge their work on its own merits. At the same time, revivals may leave behind a foundation of infrastructures - financial, institutional, social, and knowledge-based — that serve as platforms for new post-revival artists entering careers in national institutions or global markets. Revival legacies also bestow many signifiers - particularly related to ethnicity, nationality, and heritage—which post-revival artists must maneuver and manipulate.

These post-revival turns present a new set of questions. As musicians engage with the global music industry and incorporate influences from the transnational networks in which they now operate, how do they conceptualize their relationship with the home tradition? How do they reposition themselves in terms of genre or style? How does their view of their role as artist change? A range of answers to these and other questions are presented in the case studies assembled here.

Is revival itself, then, just a phase? In some senses, the answer has to be yes. One of the most significant shifts of the late twentieth and early twenty-first centuries has been the music 
industry's recasting of folk or "roots" music as world music. This has its parallel in the realm of cultural policy and conservation where local traditions have been redefined as world heritage or, in UNESCO's terms, the intangible cultural heritage of humanity. This particular shift—from an inward- to an outward-facing stance, and from local and national to global frames of referenceis of cardinal significance, as underlined in the theoretical contributions by Ronström and Sweers (this volume). In this context, post-revival sits within broader trends and processes-as captured, for example, in Arjun Appadurai's model of global flows (1996) or Ulf Hannerz's theorization of transnational connections (1996) — and enters into articulation with contemporary redefinitions of cosmopolitanism, globalization, and ethnicity as offered by these and other cultural theorists. The language of postcolonial theory is of critical importance in allowing us to conceptualize contemporary identities and intercultural relations free of the shadows cast by the old world order. Yet running across this new landscape we can clearly trace the tracks leading out from once local revival movements and, at a more global level, we can understand the contemporary trends captured in this new language as part of the continuing, age-old cycle of cultural renewal.

The ultimate drawback of the "post" option, of course, is that it still ties us to what has gone before and in so doing denies the present its own identity, its own dynamic, its own validity. Considering cultural manifestations as post-revival developments allows us to give revivalists their due by uncovering the full impact of the "work" of revival and acknowledging the universal and continuous significance of revival as a fundamental cultural process. At the same time, post-revival sows the seeds of a new beginning.

$<1>$ Contents Overview 
The thirty diverse chapters in this collection are divided into eight thematically organized sections. The first set of essays provides a theoretical foundation that paves the way for the rich selection of case studies brought together in the following seven sections. These case studies, punctuated by ethnographically informed conceptual essays, document revival initiatives and theorize their multivalent impacts on music and dance cultures around the world. The volume concludes with a short Afterword.

Section I "Towards Multiple Theories of Music Revival” comprises three essays whose authors debate the various significances of revival, deconstruct revival as cultural process, and propose new models for understanding the effects of revival in the contemporary world. Following this introductory chapter, Owe Ronström offers a framework for theorizing the discursive move from "tradition" to "heritage". Presenting revivals as decontextualizations, metaphorical transformations, and shifts between different historic, geographic, social, and cultural contexts, he goes on to explicate the critical shift from knowers to doers and marketers as revival agents and to propose that "heritage" can be seen as a homogenizing counterforce to the diversifying and globalizing forces of post- or late modernity.. Tamara Livingston reflects on how the influential revival model that she proposed in her 1999 Ethnomusicology article has subsequently been applied and critiqued by others and suggests how this model might now be expanded in light of more recent contributions to revival literature. Highlighting the participatory aspects of revivals as sites of social bonding and signification, she proposes that revivals play a vital role as powerful agents of cultural renewal and social reintegration.

Section II "Scholars and Collectors as Revival Agents" focuses our attention on the critical role played by academics, documentarians, and public folklorists in revival processes-a role that has been often been under-scrutinized. Early music scholar John Haines chronicles the 
intellectual history of antiquarians, the shared roots of musicology and ethnomusicology, and the development of universities into a modern industry. Illustrating the impact of academia on the centuries-long revival of early music, he also elucidates the links between the revival of European medieval music and folk traditions. Neil Rosenberg uses his own experiences as a folklorist and revivalist of North American traditions to deconstruct the complex relationship between the discipline of folklore and folk revivals. Following a critical review of his own seminal contributions and other revival literature, he proposes several alternative concepts to revival. Alan Jabbour's narrative account of his roles in the American old-time string revival reveals the mutuality of the relationships between documentarians and the people they document, and how these relationships shape transmission processes, funding allocation, and the establishment of new traditions. Jabbour also reminds us of the cyclical nature of revivals and the dynamics of intercultural and intergenerational flows.

Section III "Intangible Cultural Heritage, Preservation, and Policy" throws light on official local, state, and international strategies to preserve cultural traditions, highlights the structures and tensions created in top-down revivals, and explores the interface between institutional and grass-roots initiatives. Keith Howard examines the revival of South Korea's intangible cultural heritage against the backdrop of state-led and UNESCO policies as well as student-led initiatives. Through the examples of folk, percussion, shamanic, and court traditions, he challenges arguments that preservation creates sterile museum objects by demonstrating how each has been utilized as the basis of new creativity. Barley Norton chronicles transformations in the Vietnamese music and dance tradition ca trù, which in 2009 was inscribed on UNESCO's Urgent Safeguarding list. In contrast to Howard, he argues that revivalist discourse that promotes ca trì as intangible cultural heritage threatens to limit its musical and ritual meanings, to define 
its contemporary social relevance in primarily nationalistic terms, and to make it more difficult for a vital, innovative musical culture to emerge. Colin Quigley investigates the Hungarian dance house movement and its journey from 1970s urban youth culture to state promotion and UNESCO recognition. Stressing the national yet inter-ethnic and multi-state character of the dance house revival and its integration of activism and scholarship, he explores the consequences of institutionalization for the string band idiom of rural Transylvanian from which the original movement drew its inspiration.

Section IV "National Renaissance and Postcolonial Futures" charts the powerful role that revived traditions have come to play in newly independent and post-revolutionary societies. It explores tensions between notions of purism and syncretism, the interplay of continuity and transformation, and the dynamics of national institutions such as state ensembles and academies. Margaret Walker examines the revival of kathak, the classical dance of North India, which accompanied Indian independence from Britain in 1947. Proposing that the move to independence offered extensive opportunities for shifting identities, she deconstructs the evolution of kathak as a genre whose hybrid roots, stemming from Mughal courts, courtesans, and rural folk theater, were eclipsed in its reinvention as a male, devotional, Hindu tradition and symbol of middle-class Indian identity. Revisiting existing revival theories, she proposes a framework that embraces postcolonial experience and thereby sheds light on contemporary manifestations of global hybridity. Hélène Neveu Kringelbach traces the transformations of neotraditional dance in Senegal, from the influences of French colonial policy, to the role of statesponsored folkloric troops in post-independence nation-building, to the regionalist agendas of urban migrants and international emigrants. While emphasizing the role played by musical and choreographic theater in creating seductive versions of history, she argues that revival is a 
process that stretches not only in time but also in space. Tanya Merchant explores the ramifications of institutionalized musician training in a nationalist, post-Soviet project in Uzbekistan. She examines the multiple narratives of history and authenticity enacted in the teaching, aesthetic priorities, and performance of (Westernized) arranged folk music from the Soviet era and "traditional" music derived from more ancient maqom practices in the Uzbek state-run conservatory. Laudan Nooshin examines two revival movements in Iranian classical music. She contrasts the revival that emerged in the 1960s and 1970s, with its emphasis on "purity" and "authentiticy", with the more forward-looking revival following the 1979 Iranian Revolution that appealed to notions of "revival as renewal" and yet was only made possible through conditions established as part of the first. Victoria Levine analyzes the crucial roles of individual activists and bodies such as the Choctaw-Chickasaw Heritage Committee in reestablishing Native American culture in Oklahoma following more than three centuries of colonial suppression. Comparing the Choctaw and Chickasaw cases (the former growing out of a community-based, grassroots effort while the latter originated within the tribal government), she argues that these revival stories are less about loss than about finding ways to reclaim cultural identity by integrating historic practice with contemporary experience.

Section V "Recovery from War, Disaster, and Cultural Devastation" demonstrates the urgent, pragmatic, and emotional needs that revival agendas strive to fill through the reconstruction of music, dance, and other performing art traditions in communities that have been decimated by war, violence, revolution, political oppression, economic exploitation, or natural disaster. In her case study of the Homeland War (1991-1995) and its aftermath in Croatia, Naila Ceribašić describes how both official and grassroots articulations of traditional music were used as tools for coping with wartime insecurity and destruction, for uniting (and 
sometimes dividing) people along national and ethnic lines, and for reconstructing local identity and history in war-ravaged villages. In her Nicaraguan case study, Annemarie Gallaugher contextualizes the role of music in resurgence and development movements of indigenous and African-descended peoples in Latin America. She shows how the revival of Garifuna music, as an integral part of a cultural rescue movement initiated during the Sandanista revolution, facilitates the reassertion of a previously harshly suppressed identity as well as the creation of a dialogic space for renegotiating intercultural relationships. Margaret Kartomi explores how, in post-tsunami, post-conflict Aceh and Sri Lanka and post-Taliban Afghanistan, the arts have been used to help overcome trauma, restore morale, and maintain peace. On the basis of these case studies, she proposes a preliminary methodology for research into musical revivals following major catastrophes, censorship, and neglect.

Section VI "Innovations and Transformations" interrogates the dynamic tensions and paradoxes between preservation and change and illuminates how the past has served as inspiration, catalyst, and justification for changes in the present. Juniper Hill discusses how Finnish activists have used revival as a strategy to legitimate both musical innovations and social alternatives, exemplified by three distinct movements that entailed editing epic songs to bolster nation-building, embracing amateur instrumental music to rejuvenate depressed rural areas, and reentering the creative processes of ancient music to foster greater artistic freedom and experimentation. In her case study on Brazilian popular music, Denise Milstein narrates how Protest Bossa musicians from the cultural center of Rio de Janeiro strove to authenticate their political agendas by engaging musicians from the peripheral region of Bahia, who, in turn, utilized revival ingredients in their irreverent, avant-garde songs to fuel the controversial Tropicália movement. Milstein reveals how disjunctures in center-periphery perceptions 
combined with influences from mass media and changing political regimes can spur radical transformations out of revival currents. Paula Conlon chronicles the transformations of the Native American flute, from Native Plains courtship ritual, to moribund tradition, to 1960s revival, to cross-cultural New Age fusions and international Grammy-awarded commercial success. Questioning how far the flute can travel and still remain connected to its heritage, she explores the ways in which different artists have been interpreted as traditional or nontraditional, and shows how "purists" may in fact be innovators and innovators may retain elements of the tradition. Focusing on the Baltic countries, Britta Sweers explores three globalizing perspectives that have influenced discourses of revival and related processes of musical transformation: the sceptic, hyperglobal, and transformationalist. Questioning the extent to which meta-perspectives can help elucidate the impact of global flows on music revivals, she concludes that, while the examples presented support a transformationalist perspective, an adequate contemporary approach to revival requires the combination of all three perspectives.

Section VII "Festivals, Marketing, and Media" illuminates the infrastructures and industries that have developed for the display, dissemination, and marketing of revived traditions, as well as the politics of representing, commercializing, and rebranding music-cultures for new audiences and new generations of participants. Addressing the early twenty-first century resurgence of English folk music and the important role of folk festivals, Simon Keegan-Phipps and Trish Winter consider the ways in which the increasingly commercialized and professionalized infrastructure of the burgeoning folk industry coexists and interacts with the established philanthropic, anti-commercial, and amateur ethos of the folk arts. Adriana Helbig focuses on the revival of the ethnic Ukrainian midsummer ritual of Ivana Kupalo (St. John's Eve) following independence from the Soviet Union in 1991, with particular reference to gender 
discourses and identities. Against the backdrop of Kupalo celebrations as spaces within which people are invited to explore their heritage, she questions the extent to which the populist neopagan ideals of female purity and the female as mother associated with the revived rituals have influenced contemporary understandings of the feminine and the realities of women's lives in post-Soviet society. Jane Freeman Moulin centers her discussion on a popular trailer projected daily in cinemas in Hawai'i since 1992 by the movie theater chain Consolidated Amusement. She investigates the cinematic image of the trailer as a vehicle for cultural meaning, analyzing the way in which it embeds visual and auditory icons of the Hawaiian Renaissance and showing how it continues to engage contemporary perceptions of place and culture in an ethnically pluralistic, post-Renaissance Hawai' i. Richard Blaustein examines how North American oldtime fiddling has become an international cultural movement using modern technology to generate and sustain a trans-Atlantic community. Focusing in particular on the new communities and social practices enabled by the spread of the Internet, he shows how this special interest "micromusic" group uses networking tools such as Facebook, MySpace, YouTube, blogs, and listservs to pursue its nominally old-fashioned passion and fulfil present-day emotional and social needs, thereby enabling its devotees to maintain a coherent sense of distinctive identity in a rapidly changing world.

Section VIII "Diaspora and the Global Village" explores how emigrants, musicians in exile, and foreign affinity groups reclaim, recontextualize, and reinterpret musical traditions in diasporic and transnational contexts, and how these trends intersect with constructions of identity and belonging in the home territory. In her study of vocal polyphony from the Republic of Georgia, Caroline Bithell explores the multifaceted links between cycles of national revival since the mid-nineteenth century and the internationalization of Georgian polyphony in the post-Soviet 
period. Proposing that the proliferation of Georgian choirs outside Georgia might be viewed as a "third existence" of folklore and a natural extension of internal revival processes, she pays particular attention to the role of intermediaries, to learning methods that help non-Georgians to achieve a more Georgian sound, and to the motivations and rewards of different stakeholders in these cultural exchanges. Sean Williams explores attempts by the Irish diaspora to connect to an Ireland of the imagination informed by narratives of loss. Deconstructing notions of Ireland as remaining in the rural past while the diaspora hovers in the urban future, she demonstrates the generational renegotiation of authenticity, and the centuries-long, dynamic relationship between Irish and diasporic identities. Anthony Shay explores the many facets of revivalist Iranian dance in the United States. Drawing on David Guss' festival theory, Jane C. Desmond's concept of dance as a vehicle for constructing national and ethnic identity, and his own constructs of "parallel traditions" and "choreophobia," he contrasts the complexities of self-representation by Iranian Americans with the politics of representation in Iran, problematizes the orientalism and exoticism employed by both Westerners and Iranians, and explores the significance of Iranian dance for non-Iranian performers. Carol Muller considers the ways in South African jazz musicians living in exile during the height of the apartheid era reclaimed both the musics of their homeland and their musical and political freedom. Drawing on Edward Said's notion of being "out of place" and Diana Taylor's theories about archives and repertories, she extends ideas about musical revival by focusing on the use of human memory in the absence of a prior recorded archive of South African music.

Mark Slobin's afterword brings the volume to a close with an analysis of the prefix "re-" and its various connotations of reversing, re-appropriating, restoring, rebuilding, and refurbishing. He concludes by suggesting that, in looking back over our engagement with the 
past, revival scholars might best move forward by stepping sideways into interdisciplinary domains.

$<1>$ References

Allen, Ray. 2010. Gone to the Country: The New Lost City Ramblers and the Folk Revival. Urbana and Chicago: University of Illinois Press.

Appadurai, Arjun. 1996. Modernity at Large: Cultural Dimensions of Globalization. Minneapolis and London: University of Minnesota Press.

Baumann, Max Peter. 1996. "Folk Music Revival: Concepts between Regression and Emancipation." The World of Music 38, no. 3: 71-86.

Bergeron, Katherine. 1998. Decadent Enchantments: The Revival of Gregorian Chant at Solesmes. Berkeley: University of California Press

Berman, Marshall. 1982. All That is Solid Melts into Air: The Experience of Modernity. New York: Simon and Schuster.

Bigenho, Michelle. 2002. Sounding Indigenous: Authenticity in Bolivian Music Performance. New York and Basingstoke: Palgrave Macmillan.

Bithell, Caroline. 2006. "The Past in Music: Introduction.” In The Past in Music, edited by Caroline Bithell. Ethnomusicology Forum 15, no. 1: 3-16.

- Transported by Song: Corsican Voices from Oral Tradition to World Stage. Lanham, MD: Scarecrow Press, 2007.

Blum, Stephen, Philip V. Bohlman, and Daniel M. Neuman (eds.). 1993. Ethnomusicology and Modern Music History. Urbana and Chicago: University of Illinois Press. 
Boden, Margaret. 2004. The Creative Mind: Myths and Mechanisms. Second Edition. New York: Routledge.

Bohlman, Philip V. 1988. The Study of Folk Music in the Modem World. Bloomington: Indiana University Press.

Boissevain, Jeremy (ed). 1992. Revitalizing European Rituals. London and New York: Routledge.

Boyes, Georgina. 1993. The Imagined Village: Culture, Ideology and the English Folk Revival. Manchester: Manchester University Press.

Boym. Svetlana. 2001. The Future of Nostlagia. New York: Basic Books.

Briggs, Charles. 1996. "The Politics of Discursive Authority in Research on the 'Invention of Tradition'." Cultural Anthropology 11: 435-469.

Brocken, Michael. 2003. The British Folk Revival, 1944-2002. Aldershot: Ashgate.

Brown, Michael F. 2003. Who Owns Native Culture? Cambridge, MA: Harvard University Press.

Buchanan, Donna A. 2006. Performing Democracy: Bulgarian Music and Musicians in Transition. Chicago: University of Chicago Press.

Burns, Robert G. H. 2012. Transforming Folk: Innovation and Tradition in English Folk-rock Music. Manchester: Manchester University Press.

Butt, John. 2002. Playing with History: The Historical Approach to Musical Performance. Cambridge: Cambridge University Press.

Cantwell, Robert. 1996. When We Were Good: The Folk Revival. Cambridge, MA and London: Harvard University Press.

Child, Francis James (ed.). 1861. English and Scottish Ballads. London: Sampson Low. 
Cohen, Ronald (ed.). 1995. “Wasn't that a time!" Firsthand Accounts of the Folk Music Revival. Lanham, MA: Scarecrow Press.

Cohen, Ronald D. 2002. Rainbow Quest: The Folk Music Revival and American Society, 19401970. Amherst: University of Massachusetts Press.

Cohen, Joël and Herb Snitzer. 1985. Reprise: the Extraordinary Revival of Early Music. New York: Little, Brown and Company.

Connerton, Paul. 1989. How Societies Remember. Cambridge: Cambridge University Press.

Denisoff, R. Serge. 1971. Great Day Coming: Folk Music and the American Left. Urbana and London: University of Illinois Press.

DeTurk, David, and A. Poulin Jr. (eds.). 1967. The American Folk Scene: Dimensions of the Folksong Revival. New York: Dell.

Dorson, Richard M. 1950. "Folklore and Fakelore." American Mercury 70: 335-343.

Dunaway, David King, Molly Beer, and Peter Seeger. 2010. Singing out: An oral history of America's folk music revivals. Oxford: Oxford University Press.

Emery, Elizabeth, and Laura Morowitz. 2003. Consuming the Past: The Medieval Revival in Fin De Siècle France. Aldershot: Ashgate.

Emoff, Ron. 2002. Recollecting from the Past: Musical Practice and Spirit Possession on the East Coast of Madagascar. Middletown, Conn.: Wesleyan University Press.

Eyerman, Ron, and Andrew Jamison. 1998. Music and Social Movements: Mobilizing Traditions in the Twentieth Century. Cambridge: Cambridge University Press.

Feintuch, Burt. 1993. “Musical Revival As Musical Transformation.” In Transforming Traditions: Folk Music Revivals Examined, edited by Neil Rosenberg, 183-193. Urbana: University of Illinois Press. 
Feintuch, Bert. 2006. "Revivals on the Edge: Northumberland and Cape Breton—A Keynote." Yearbook for Traditional Music 38: 1-17.

Filene, Benjamin. 2000. Romancing the Folk: Public Memory and American Roots Music. Chapel Hill: University of North Carolina Press.

Fujie, Linda (ed.). 1996. Folk Music Revival in Europe. World of Music 38, no. 3.

Gandhi, Leela. 1998. Postcolonial Theory: A Critical Introduction. Edinburgh: Edinburgh University Press.

Goertzen, Chris. 1997. Fiddling for Norway: Revival and Identity. Chicago: University of Chicago Press.

Goodman, Jane E. 2005. Berber Culture on the World Stage: From Village to Video. Bloomington, IN: Indiana University Press.

Groom, Bob. 1971. The Blues Revival. London: November Books Ltd.

Halbwachs, Maurice. 1925. Les cadres sociaux de la mémoire. Paris: Librairie Félix Alcan. (New edition: Albin Michel, 1994.)

— 1950. La mémoire collective. Paris: Presses Universitaires de France. (New edition: Albin Michel, 1997.)

Hannerz, Ulf. 1996. Transnational Connections: Culture, People, Places. London and New York: Routledge.

Harris, Rachel. 2004. Singing the Village: Music, Memory and Ritual among the Sibe of Xinjiang. Oxford and New York: Oxford University Press.

Haskell, Harry. 1988. The Early Music Revival: A History. London: Thames and Hudson. 
Hill, Juniper. 2007. “'Global Folk Music’ Fusions: The Reification of Transnational Relationships and the Ethics of Cross-Cultural Appropriations in Finnish Contemporary Folk Music." Yearbook for Traditional Music 39: 50-83.

—. 2009. "The Influence of Conservatory Folk Music Programs: The Sibelius Academy in Comparative Context." Ethnomusicology Forum 18, no. 2: 205-239.

Hobsbawm, Eric. 1983. “Introduction: Inventing Traditions.” In The Invention of Tradition, edited by Eric Hobsbawm and Terence Ranger, 1-14. Cambridge: Cambridge University Press.

Hodder, Ian, et al. (eds.). 1995. Interpreting Archaeology: Finding Meaning in the Past. London and New York: Routledge.

Kapchan, Deborah. 2007. Traveling Spirit Masters: Moroccan Gnawa Trance and Music in the Global Marketplace. Middletown, Conn.: Wesleyan University Press.

Kearney Guigné, Anna. 2008. Folksongs and Folk Revival: The Cultural Politics of Kenneth Peacock's Songs of the Newfoundland Outports. St. John's: ISER.

Keegan-Phipps, Simon. 2007. "Déja Vu? Folk Music, Education, and Institutionalization in Contemporary England." Yearbook for Traditional Music 39: 84-107.

Kirkman, Andrew. 2010. The Cultural Life of the Early Polyphonic Mass: Medieval Context to Modern Revival. Cambridge: Cambridge University Press.

Klein, Debra L. 2007. Yorùbá Bàtá Goes Global: Artists, Culture Brokers, and Fans. Chicago and London: University of Chicago Press.

Koskoff, Ellen (ed). 2005. Music Cultures in the United States: An Introduction. New York and London: Routledge. 
Laušević, Marjana. 2007. Balkan Fascination: Creating an Alternative Music Culture in America. New York and Oxford: Oxford University Press.

Leech-Wilkinson, Daniel. 2002. The Modern Invention of Medieval Music: Scholarship, Ideology, Performance. Cambridge: Cambridge University Press.

Lessig, Lawrence. 2004. Free Culture: How Big Media Uses Technology and the Law to Lock Down Creativity. New York: Penguin Press.

Lessig, Lawrence. 2008. Remix: Making Art and Commerce Thrive in the Hybrid Economy. New York: Penguin Press.

Lieberman, Robbie. 1995. My Song is my Weapon: People's Songs, American Communism, and the Politics of Culture, 1930-50. Urbana: University of Illinois Press.

Linn, Karen. 1994. That Half-Barbaric Twang: The Banjo in American Popular Culture. Urbana: University of Illinois Press.

Linton, Ralph. 1943. "Nativistic Movements.” American Anthropologist 45: 230-240.

Lipsitz, George. 1990. Time Passages: Collective Memory and American Popular Culture. Minneapolis, MN: University of Minnesota Press.

Livingston, Tamara E. 1999. "Music Revivals: Towards a General Theory.” Ethnomusicology 43, no. 1: 66-85.

Lomax, Alan. 1968. Folk Song Style and Culture. Washington: American Association for the Advancement of Science.

Longinović, Tomislav. 2000. "Music Wars: Blood and Song at the End of Yugoslavia." In Music and the Racial Imagination, edited by Ronald Radano and Philip V. Bohlman, 622-643. Chicago: University of Chicago Press.

Lord, Albert B. 1960. The Singer of Tales. Cambridge: Harvard University Press. 
Lowenthal, David. 1998. The Heritage Crusade and the Spoils of History. Cambridge: Cambridge University Press.

Mackinnon, Niall L. 1993. The British Folk Scene: Musical Performance and Social Identity. Buckingham, UK and Philadelphia: Open University Press.

McCann, Anthony. 2001. “All That Is Not Given Is Lost: Irish Traditional Music, Copyright, and Common Property.” Ethnomusicology 45, no. 1: 89-106.

McGraw, Andrew. 2009. "Radical Tradition: Balinese Musik Kontemporer.” Ethnomusicology 53, no. 1: 115-141.

Meintjes, Louise. 2003. Sound of Africa! Making Music Zulu in a South African Studio. Durham: Duke University Press.

Merriam, Alan P. 1964. The Anthropology of Music. Evanston, IL: Northwestern University Press.

Mills, Sherylle. 1996. "Indigenous Music in the Law: An Analysis of National and International Legislation." Yearbook for Traditional Music 28: 57-85.

Mitchell, Gillian. 2007. The North American Folk Music Revival: Nation and Identity in the United States and Canada. Aldershot: Ashgate.

Morrow, Michael. 1978. "Musical Performance and Authenticity." Early Music 6, no. 2: 233246.

Munro, Ailie. 1984. The Folk Music Revival in Scotland. London: Kahn \& Averill.

Nettl, Bruno. 1985. The Western Impact on World Music: Change, Adaptation and Survival. New York : Schirmer.

Neuenfeldt, Karl (ed.). 2002. Indigenous Popular Music in North America: Continuations and Innovations. Special issue, The World of Music 44, no. 1. 
Olson, Laura J. 2004. Performing Russia: Folk Revival and Russian Identity. New York: RoutledgeCurzon.

Palmer, Larry. 1989. Harpsichord in America: A 20th Century Revival. Bloomington: Indiana University Press.

Pettan, Svanibor (ed). 1998. Music, Politics and War: Views from Croatia. Zagreb: Institute of Ethnology and Folklore.

Pihl, Marshall. 1994. The Korean Singer of Tales. Cambridge, MA: Harvard University Press. Porter, James (ed.). 1997. Folklore and Traditional Music in the Former Soviet Union and Eastern Europe. Los Angeles: University of California Press.

Reuss, Richard A. with Reuss, JoAnne C. 2000. American Folk Music and Left-Wing Politics. Lanham, MA: Scarecrow Press.

Rice, Timothy. 1994. May It Fill Your Soul: Experiencing Bulgarian Music. Chicago: University of Chicago Press.

Romero, Raúl R. 2001. Debating the Past: Music, Memory, and Identity in the Andes. Oxford and New York: Oxford University Press.

Ronström, Owe. 1996. "Revival Reconsidered.” The World of Music 38, no. 3: 5-20.

—. 1998. "Revival in Retrospect: The Folk Music and Folk Dance Revival.” Traditional Dance in Europe: Revival Activities, 4 November. Bulletin from the European Center for Traditional Culture, Budapest.

Rosenberg, Neil V. 1985. Bluegrass: A History. Urbana: University of Illinois Press.

Rosenberg, Neil V. 1991. “'An Icy Mountain Brook': Revival, Aesthetics, and the Coal Creek March." Journal of Folklore Research 28, no. 2-3: 221-240. 
Rosenberg, Neil. 1993. "Introduction.” In Transforming Traditions: Folk Music Revivals Examined, edited by Neil Rosenberg, 1-26. Urbana: University of Illinois Press.

Rosenberg, Neil (ed.). 1993. Transforming Traditions: Folk Music Revivals Examined. Urbana: University of Illinois Press.

Sapoznik, Henry. 2006. Klezmer! Jewish Music from Old World to Our World. New York: Schirmer Books.

Scully, Michael F. 2008. The Never-Ending Revival: Rounder Records and the Folk Alliance. Urbana and Chicago: University of Illinois Press.

Seeger, Anthony. 1992. "Ethnomusicology and Music Law." Ethnomusicology 36, no. 3: 345359.

Sharp, Cecil. 1907. English Folksong: Some Conclusions. London: Simpkin.

Sharp, Cecil. 1917. "Introduction.” In English Folk Songs from the Southern Appalachians, comprising 122 songs and ballads, and 323 tunes, compiled by Olive Dame Campbell and Cecil Sharp. London: G.P. Putnam's Sons.

Shelemay, Kay Kaufman. 1998. Let Jasmine Rain Down: Song and Remembrance among Syrian Jews. Chicago and London: University of Chicago Press.

Slobin, Mark. 1983. "Rethinking 'Revival' of American Ethnic Music.” New York Folklore 9, no. 3-4: 37-44.

Slobin, Mark. 1993. Subcultural Sounds: Micromusics of the West. Hanover, New Hampshire: University Press of New England (Wesleyan University Press).

Slobin, Mark (ed.). 1996. Retuning Culture: Musical Changes in Central and Eastern Europe. Durham, NC: Duke University Press. 
Slobin, Mark. 2002. American Klezmer: Its Roots and Offshoots. Berkeley, CA and London: University of California Press.

Solís, Ted. 2004. Performing Ethnomusicology: Teaching and Representation in World Music Ensembles. Berkeley: University of California Press.

Stekert, Ellen. 1966. “Cents and Nonsense in the Urban Folksong Movement: 1930-1966.” In Folklore and Society: Essays in Honor of Benj. A. Botkin, edited by Bruce Jackson, 153168. Hatboro, Pennsylvania: Folklore Associates.

Stock, Jonathan. 1996. Musical Creativity in Twentieth-Century China: Abing, His Music, and Its Changing Meanings. Rochester, NY: University of Rochester Press.

Stock, Jonathan. 2004. "Peripheries and Interfaces: the Western Impact on Other Music." In The Cambridge History of Twentieth-Century Music, edited by Nicholas Cook and Anthony Pople. Cambridge: Cambridge University Press.

Sweers, Britta. 2005. Electric Folk: The Changing Face of English Traditional Music. Oxford and New York: Oxford University Press.

Taruskin, Richard. 1982. "On Letting the Music Speak for Itself: Some Reflections on Musicology and Performance.” The Journal of Musicology 1, no. 3: 338-349.

—. 1984. "The Authenticity Movement Can Become a Positivistic Purgatory, Literalistic and Dehumanizing." Early Music 12, no. 1: 3-12.

—. 1992. "Tradition and Authority." Early Music 20, no. 2: 311-325.

Taylor, Timothy D. 1997. Global Pop: World Music, World Markets. London: Routledge.

- 2007. Beyond Exoticism: Western Music and the World. Durham, NC: Duke University Press. 
Titon, Jeff Todd. 1993. "Reconstructing the Blues: Reflections on the 1960s Blues Revival.” In Transforming Tradition, edited by Neil V. Rosenberg, 220-240. Urbana: University of Illinois Press.

Titon, Jeff Todd. 1994. Early Downhome Blues: a Musical and Cultural Analysis. Second Edition. Chapel Hill: University of North Carolina Press.

Turino, Thomas. 2008. Music as Social Life: The Politics of Participation. Chicago and London: University of Chicago Press.

Ucko, Peter J. (ed.). 1995. Theory in Archaeology: A World Perspective. London and New York: Routledge.

UNESCO. 2003. "Frequently Asked Questions: Convention for the Safeguarding of the Intangible Cultural Heritage.” http://portal.unesco.org/culture/fr/ev.phpURL_ID $=21606 \& U R L \_D O=D O \_T O P I C \& U R L \_S E C T I O N=201 . h t m l$

Waitzman, Daniel. 1980. "Historical Versus Musical Authenticity: The Performer's View." The American Recorder: A Journal for Early Music 21, no. 1: 11-13.

Wallace, Anthony F. C. 1956. "Revitalization Movements.” American Anthropologist 58: 26481.

Wang Ying-fen. 2003. “Amateur Music Clubs and State Intervention: The Case of Nanguan Music in Postwar Taiwan.” Special Issue: "Cultural Policy and Traditional Performing Arts in Asia." Journal of Chinese Ritual, Theater and Folklore 141: 95-168.

Weisethaunet, Hans, and Ulf Lindberg. 2010. “Authenticity Revisited: The Rock Critic and the Changing Real.” Popular Music and Society 33, no. 4: 465-485.

Weissman, Dick. 2005. Which Side Are You On? An Inside History of the Folk Music Revival in America. London: Continuum. 
Wilson, William A. 1976. Folklore and Nationalism in Modern Finland. Bloomington: Indiana University Press.

\section{Zemp, Hugo. 1996. "The/An Ethnomusicologist and the Record Business." Yearbook for}

Traditional Music 28: 36-56.

Zon, Bennett. 1999. The English Plainchant Revival. Oxford: Oxford University Press.

\footnotetext{
${ }^{1}$ Rosenberg (1993: 20) dismisses Hobsbawm's explanation of invented traditions because of its focus on the formal activities of governments and institutions rather than on the informal aspects of culture and customs that Rosenberg feels are more relevant to folk revivals. In this volume, we analyze the important role that states, institutions, and various governmental policies wield in revival processes, in addition to more grassroots-driven revivals (see chapters by Levine, Howard, Merchant, Norton, and Quigley).

${ }^{2}$ Lomax's theory of Cantometrics (1968) was perhaps the last major study in the field of ethnomusicology to collect data from and theorize about a multitude of music cultures from around the world. The theory received heavy criticism, and since then the majority of ethnomusicologists have focused on conducting individual case studies in one region at a time (or, in some cases, following one ethnic group or affinity group across a diaspora).

${ }^{3}$ See the many monographs on British folk revivals (Boyes 1993, Brocken 2003, Munro 1984), the Norwegian fiddle revival (Goertzen 1997), the Russian folk revival (Olson 2004), various North American folk revivals (Allen 2010, Cantwell 1996, Cohen 1995 and 2002, Dunway, Beer, and Seeger 2010, Groom 1971, Kearney Guigné 2008, Mitchell 2007, Scully 2008, Weissman 2005), Gregorian and plainchant revivals (Bergeron 1998, Zon 1999), and various overlapping early music revivals (Cohen and Snitzer 1985, Emery and Morowitz 2003, Haskell 1988, Kirkman 2010, Palmer 1989). For Central and Eastern Europe, see also the contributions to Slobin 1996. Other monographs that do not include explicit reference to revival in their titles but nonetheless focus on processes of revival, revitalization, and/or recontextualization (often indicated by the formulation "from . . . to ...") include Bithell 2007, Goodman 2005, Sapoznik 2006, Slobin 2002, and Sweers 2005.

${ }^{4}$ Filene (2000: 5-6) proposes that these cultural brokers often strove to cloak their own power so as not to undermine the authenticity of the performers they promoted.

${ }^{5}$ The majority of the revival literature on Western European musics has focused on folk/traditional music and early music. Many insights could yet be gained by additional, future research on revival themes in other eras of Western art music and in popular musics.

${ }^{6}$ In some cases, even aesthetic motivations may be reactionary. For example, Nicholas Cook suggests that the neoclassical movement of nineteenth-century Europe strove to recapture what were perceived as timeless classical aesthetic values in contrast to the virtuosity and showmanship culture of the piano wars (personal communications, November 2012, Cambridge, England).

${ }^{7}$ We use the term "activist" in a broad sense to denote a continuum from "intentional" to "militant."

${ }^{8}$ This formulation, which appeared in the Communist Manifesto, lent itself as the title of Marshall Berman's seminal book All That is Solid Melts into Air: The Experience of Modernity (first published 1982).

${ }^{9}$ Classic texts on collective memory include Halbwachs 1925 and 1950 (republished 1994 and 1997), Connerton 1989, and Lipsitz 1990.

${ }^{10}$ For a broader approach to ethnomusicology's engagement with the study of history see Blum, Bohlman, and Neuman 1993. Monographs in which the invocation of the past, or the role of memory, in the musical expression of the present is a central theme include Emoff 2002, Harris 2004, Romero 2001, and Shelemay 1998.

${ }^{11}$ In Stekert's analysis, the "new aesthetic" is one of four categories, the others being traditional singers, imitators, and utilizers (the latter including "urban pop" and "urban art" groups).

${ }^{12}$ Monographs that examine musicians and musical cultures in transition between local and global worlds include Bithell 2007, Buchanan 2006, Goodman 2005, Kapchan 2007, Klein 2007.
} 
${ }^{13}$ The notion of the "authenticity police" (applied to those who adopt a more traditionalist approach to performing the music of the past) puts in frequent appearances in the context of early music. See also Nooshin, this volume, with reference to Iranian classial music.

${ }^{14}$ For monographs that take authenticity and its negotiation by indigenous performers and producers as their main focus, see Bigenho 2002 and Meintjes 2003.

${ }^{15}$ Weisethaunet and Lindberg (2010) provide an overview of how discourse in different fields has focused on different authenticity criteria: the author-work relationship in art discourse; the autonomy of self in existentialist philosophy; the self in contrast to the culture industry and mass society in the Frankfurt school of philosophy; feeling and expression in rock criticism; and expression of social conditions and nationalism, as well as opposition to cultural grey-out, in folklore.

${ }^{16}$ A related strategy famously used by John and Alan Lomax was to seek out musicians serving life sentences who, due to their lengthy imprisonment, had been isolated from recent commercial music.

${ }^{17}$ For a more general discussion of hybridity and creolization as creative interplay, authentic experience, and contemporary reality, see Hannerz 1996.

${ }^{18}$ See, for example, the website for Studies on Cultural Transfer and Transmission (www.soctat.org).

${ }^{19}$ Burns (2012), for example, argues that the presentation of English folk music at world music festivals has stimulated significant growth in folk music audiences at home since the mid-1990s.

${ }^{20}$ For further accounts of the institutionalization of folk and traditional musics, see Hill 2009, Keegan-Phipps 2007, McGraw 2009, Nettl 1985, Stock 1996 and 2004, and Wang 2003. 